\title{
Review
}

\section{Ethnobiology, socio-economics and management of mangrove forests: A review}

\author{
Bradley B. Walters ${ }^{\mathrm{a}, *}$, Patrik Rönnbäck ${ }^{\mathrm{b}}$, John M. Kovacs ${ }^{\mathrm{c}}$, Beatrice Crona ${ }^{\mathrm{b}}$, Syed Ainul Hussain ${ }^{\mathrm{d}}$, \\ Ruchi Badola ${ }^{\mathrm{d}}$, Jurgenne H. Primavera ${ }^{\mathrm{e}}$, Edward Barbier ${ }^{\mathrm{f}}$, Farid Dahdouh-Guebas ${ }^{\mathrm{g}, \mathrm{h}}$ \\ ${ }^{a}$ Geography \& Environment, Mount Allison University, Sackville, NB E4L 1A7, Canada \\ ${ }^{\mathrm{b}}$ Systems Ecology, Stockholm University, S106 91 Stockholm, Sweden \\ ${ }^{\mathrm{c}}$ Geography, Nipissing University, North Bay, ON P1B 8L7, Canada \\ ${ }^{\mathrm{d}}$ Wildlife Institute of India, P.O. Box 18, Dehra Dun 248001, Uttarakhand, India \\ e Aquaculture Department, Southeast Asian Fisheries Development Center, Tigbauan, IloIlo 5021, Philippines \\ ${ }^{\mathrm{g}}$ Biocomplexity Research Focus, (Complexité et Dynamique des Systèmes Tropicaux), Département de Biologie des Organismes, Université Libre de Bruxelles - ULB, \\ Campus du Solbosch, CP 169, Avenue Franklin D. Roosevelt 50, B-1050 Bruxelles, Belgium \\ ${ }^{\mathrm{h}}$ Biocomplexity Research Focus c/o Laboratory of Plant Biology and Nature Management, Mangrove Management Group, Vrije Universiteit Brussel - VUB, \\ Pleinlaan 2, B-1050 Brussel, Belgium
}

\section{A R T I C L E I N F O}

\section{Article history:}

Received 2 March 2007

Received in revised form 27 January 2008

Accepted 15 February 2008

Available online 4 March 2008

\section{Keywords:}

Mangrove

Anthropogenic disturbance

Human ecology

Non-timber forest product

Economic valuation

Ecosystem service

Forest management

\begin{abstract}
A B S T R A C T
There is growing research interest in the ethnobiology, socio-economics and management of mangrove forests. Coastal residents who use mangroves and their resources may have considerable botanical and ecological knowledgeable about these forests. A wide variety of forest products are harvested in mangroves, especially wood for fuel and construction, tannins and medicines. Although there are exceptions, mangrove forest products are typically harvested in a small-scale and selective manner, with harvesting efforts and impacts concentrated in stands that are closer to settlements and easiest to access (by land or by sea). Mangroves support diverse, local fisheries, and also provide critical nursery habitat and marine productivity which support wider commercial fisheries. These forests also provide valuable ecosystem services that benefit coastal communities, including coastal land stabilization and storm protection. The overlapping of marine and terrestrial resources in mangroves creates tenure ambiguities that complicate management and may induce conflict between competing interests. Mangroves have been cut and cleared extensively to make way for brackish water aquaculture and infrastructure development. More attention is now given to managing remaining forests sustainably and to restoring those degraded from past use. Recent advances in remotely sensed, geo-spatial monitoring provide opportunities for researchers and planners to better understand and improve the management of these unique forested wetlands.
\end{abstract}

\section{Contents}

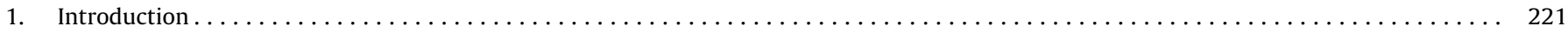

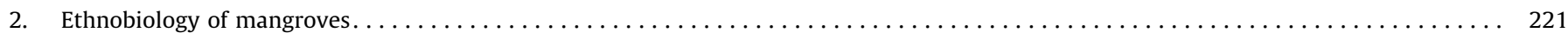

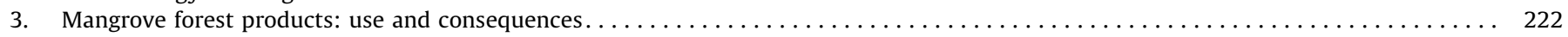

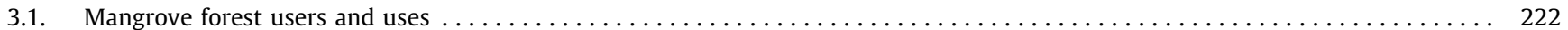

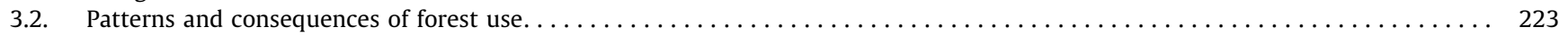

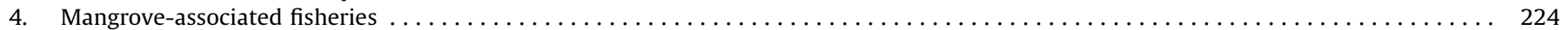

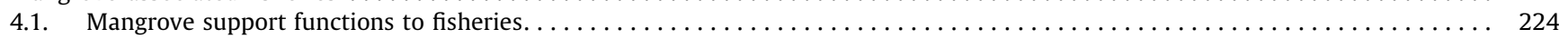

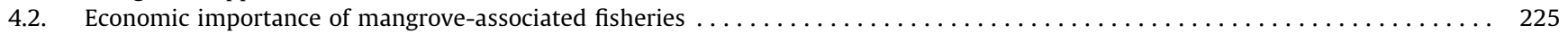

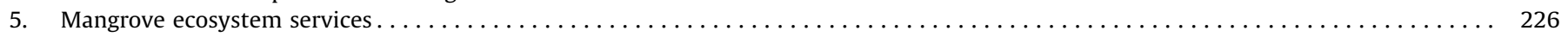

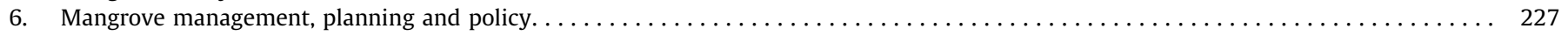

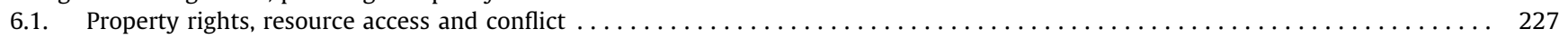

\footnotetext{
* Corresponding author. Tel.: +1 506364 2323; fax: +1 5063642625 .

E-mail address: bwalters@mta.ca (B.B. Walters).
} 


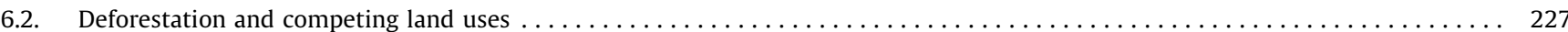

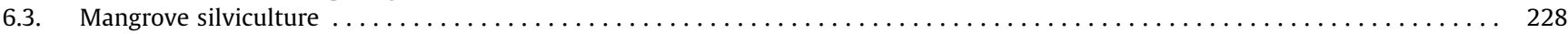

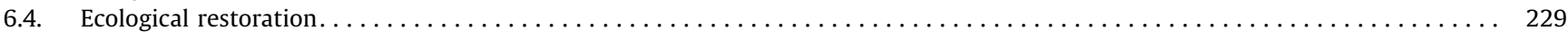

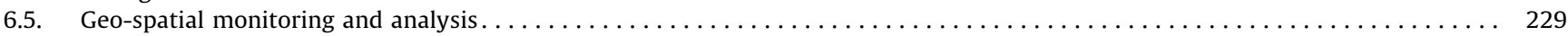

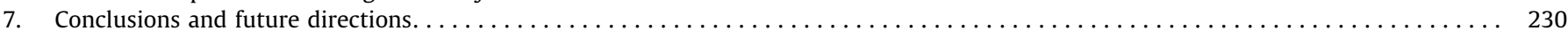

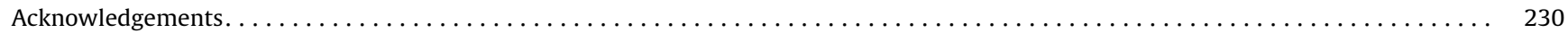

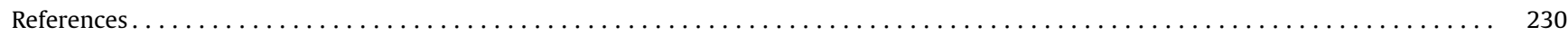

\section{Introduction}

Mangroves have been extensively studied for decades by botanists, ecologists and marine scientists (Macnae, 1968; Chapman, 1976; Saenger et al., 1983; Tomlinson, 1986; Kathiresan and Bingham, 2001; Lacerda, 2002). Yet, it was not until the 1980 s and early 1990s that significant research attention was brought to bear on the human interactions with these unique forested wetlands (FAO, 1985; Hamilton et al., 1989; FAO, 1994; Cormier-Salem, 1999). Earlier works were mostly descriptive, documenting the status and uses of mangroves by coastal communities (e.g., Walsh, 1977; Taylor, 1982; Christensen, 1982; Kunstadter et al., 1986; Field and Dartnall, 1987; Diop, 1993; Lacerda, 1993). By contrast, recent research on mangroves is more analytical, examining humans as ecological agents of disturbance and change in mangrove ecosystems. These studies have applied a mix of ecological, economic, ethnographic, historical and geo-spatial methods to quantify the diverse values of mangrove forests and to probe cause-effect relationships between people and mangroves in a variety of geographic, cultural and political-economic contexts (e.g., Dewalt et al., 1996; Ellison and Farnsworth, 1996; Ewel et al., 1998b; Rönnbäck, 1999; Vandergeest et al., 1999; Kovacs, 2000; Barnes, 2001; Walters, 2003, 2005b; Dahdouh-Guebas et al., 2006a; Lopez-Hoffman et al., 2006).

This review paper synthesizes research on the ethnobiology, socio-economics and management of mangrove forests, and also includes a brief review of geo-spatial monitoring tools as these have been applied to study mangroves. These topics span an enormously diverse range of literature. As such, different subtopics are necessarily dealt with succinctly. An attempt was made to include the most significant publications as well as a good number of the less noted, but also important research works. The extensive bibliography can serve as a resource for readers interested in further exploration of the subject.

Population pressure is typically greatest along the coast, so it is little surprise that human influences on the world's mangrove forests are significant and growing. Mangroves have been cleared and degraded on an alarming scale during the past four decades (Valiela et al., 2001; Wilkie and Fortuna, 2003; Duke et al., 2007), yet they remain an important source of wood and food products and provide vitally important environmental services for coastal communities throughout the tropics (Balmford et al., 2002). These values still receive relatively little attention or recognition from government policy-makers and the development community, and the myriad influences people have on these forests continue to be overlooked by many mangrove researchers. It is hoped that this review paper will provide some corrective to this neglect.

\section{Ethnobiology of mangroves}

Local ecological knowledge (LEK) or traditional ecological knowledge (TEK) are closely related concepts that are broadly inclusive of many different types of ecologically relevant knowledge, ranging from traditional use of specific plants and animals and essential knowledge critical to harvesting natural resources, through complex understandings of the functioning of local ecosystems, to cultural beliefs and religious views of human-environment relations (Berkes, 1999; Davis and Wagner, 2003).

There is an implicit assumption that most LEK is accumulated through experiences of close contact with the natural environment, and therefore locality plays a large part in shaping this knowledge (Davis and Wagner, 2003). The local scale has also been shown to be important in resource extraction patterns and resulting impacts on mangroves (Tomlinson, 1986; Ewel et al., 1998b; Kovacs, 1999; Dahdouh-Guebas et al., 2000a, 2000b, 2006a; Walters, 2005a, 2005b; Lopez-Hoffman et al., 2006). The role of LEK in shaping resource use in mangroves is therefore of great interest for management of these ecosystems. There is much opportunity to integrate indigenous knowledge into contemporary frameworks for conservation and sustainable management, or in a priori understanding of forest dynamics and local dependency using ethnoscientific approaches (Rist and Dahdouh-Guebas, 2006) and modeling (Berger et al., 2008). Studies of mangrove LEK and ethnobiology can be split into two general categories: one focusing on the functioning of the ecosystem, including knowledge of ecological processes and how different ecological components interact with each other; the other focusing more on specific species or taxa and their use for anthropocentric purposes, often termed ethnotaxonomy or ethnobotany (Berlin, 1973).

Studies in Mexico, the Philippines, Tanzania, Kenya, India and Venezuela are worth briefly describing as examples where LEK representing basic ecosystem dynamics has been documented. Kovacs (2000) showed how Mexican fishermen have extensive knowledge of mangrove system dynamics, including previously undocumented sources of local environmental disturbance that help explain changes in the forest over time. Similarly, Walters (2003, 2005b) sought the knowledge of local fishermen and coastal residents in the Philippines to assist in mapping and explaining changes to the distribution of mangrove forests. Tobisson et al. (1998) found intricate LEK within Zanzibar fishing communities relating to tidal patterns and currents, but linked to mangroves and associated fisheries. In Kenya, Crona (2006) similarly showed a large body of LEK related to complex ecological linkages between mangroves and the surrounding seascape, and noted marked differences in local peoples' knowledge based on their gear types and modes of resource extraction from the mangrove. This heterogeneous distribution of LEK between user groups is a common theme throughout much LEK work on mangroves and other systems (Kovacs, 2000; Dahdouh-Guebas et al., 2000b; Ghimire et al., 2004; Vayda et al., 2004; Walters, 2004; Hernández Cornejo et al., 2005; Dahdouh-Guebas et al., 2006a). The benefit of such heterogeneity and spatially distributed LEK is that it can be valuable for documenting and understanding variations in patterns of mangrove use and change that would otherwise not be apparent with larger-scale scientific assessments and monitoring (Kovacs, 2000). 
Understanding of ecosystem dynamics by local communities has also proven valuable as a background to reconstruct historical use and impact on mangroves (Walters, 2003; Dahdouh-Guebas et al., 2004, 2005b), although efforts should be made to validate such information before it is applied to policy and management decisions (Kovacs, 2000; Hernández Cornejo et al., 2005). Validation, in this sense, means sound interpretation by cross-checking statements with other information sources, including pre-existing historical documents, data from remotely sensed imagery and modeling, and experimental field-testing (Kovacs et al., 2001a, b; Vayda et al., 2004; Hernández Cornejo et al., 2005; Bart, 2006; Lopez-Hoffman et al., 2006). This historical aspect of LEK can, when used in conjunction with scientific results, also increase the chance of including important ecological information potentially missed by short-term duration scientific studies (Moller and Berkes, 2004; Bart, 2006). Examples of this can be seen in findings on the role of caterpillars and hurricanes as agents of mangrove forest disturbance in Mexico (Kovacs, 2000), and in information on sea urchin infestations in Kenya (Crona, 2006).

The second knowledge category is represented by ethnobotany which relates to taxonomy and use of specific plants for different purposes. This is a better-documented field than the LEK of system dynamics reviewed above, although very fragmentary from a global perspective. In many coastal communities, mangrove dependence is high and both wood and non-wood products are used for a multitude of purposes. Discussions of LEK as this pertains to mangrove resource use are embedded in subsequent sections of the paper that detail forest and aquatic resource uses. Nonetheless, a few general comments and examples are warranted here.

Like the aforementioned studies on knowledge of basic ecology, LEK that is related to mangrove resource use is often well developed, but heterogeneous between and within coastal communities in ways that typically reflect their varied experience and dependence on the use of particular resources. For example, Lopez-Hoffman et al. (2006) found sharp differences in the perceptions and practices of older, more experienced versus younger, less experienced mangrove wood harvesters in Venezuela. The same is true for Kenyan mangrove users, as those with greater experience were better able than others to identify forest vegetation decline (Dahdouh-Guebas et al., 2000b). Similarly, studies of coastal residents in the Philippines who were engaged in the local silviculture of mangrove trees revealed that knowledge among planters about propagation and management was considerable, but varied enormously depending on personal experience and opportunities to learn from others more knowledgeable. The differences in knowledge had significant consequences for the relative success of individual mangrove tree planters (Vayda et al., 2004; Walters, 2004).

However, as knowledgeable as local people were sometimes found to be, it is notable that mangrove users in the aforementioned Venezuelan and Philippine cases were sometimes found to act in ways that were inconsistent with their knowledge and avowed beliefs by, for example, over-cutting and clearing mangroves that they otherwise viewed as important to protect (Vayda and Walters, 1999; Walters, 2004; Lopez-Hoffman et al., 2006). This gap between knowledge and behavior, also known as 'cognitive dissonance' (Festinger, 1957), is displayed by most humans to various degrees and is often caused by conflicting interests or incentives. While this does not invalidate the LEK per se, such knowledge should not be assumed to always guide the behavior of local users in terms of resource use, etc. (Vayda et al., 2004; Bart, 2006). Economic incentives, property rights and participation in the management process are also likely to influence such behavior.

\section{Mangrove forest products: use and consequences}

\subsection{Mangrove forest users and uses}

Non-timber forest products are recognized as important economic resources, particularly to rural, marginalized communities (Vedeld et al., 2004). Many coastal communities in the tropics are characterized by relative geographic isolation, chronic poverty and significant dependence on the harvest of marine and coastal resources for their livelihood (Kunstadter et al., 1986). The majority of people living in or near mangrove areas derive their principal income from fishing and related activities. The direct harvest of mangrove wood and plants is rarely a full-time occupation for them, but a great many rely on these products to meet subsistence needs for fuel and construction materials, and for others the harvest and sale of mangrove forest products is an important income supplement (Christensen, 1982; FAO, 1985, 1994; Kunstadter et al., 1986; Diop, 1993; Lacerda et al., 1993; Spalding et al., 1997; Glaser, 2003; Walters, 2005a; Lopez-Hoffman et al., 2006; Rönnbäck et al., 2007a).

The two most widespread uses of mangrove wood are for fuel and construction. Many common mangrove tree species, e.g., Rhizophora species produce wood that is dense, hard and often rich in tannins (FAO, 1994; Bandaranayake, 1998). Such wood burns long and hot, and so is highly attractive for making charcoal or consuming directly as firewood (Brown and Fischer, 1918; Chapman, 1976; Christensen, 1982, 1983b; Taylor, 1982; Bhattacharyya, 1990; Ewel et al., 1998a; Walters, 2005a; DahdouhGuebas et al., 2006a). The harvest of mangrove for fuelwood is widespread throughout the coastal tropics (Fig. 1A and D). In some countries, mangrove wood historically formed an important commercial fuel for industries like bakeries and clay-firing kilns, although this is less common today because of the ready availability of alternative fuels, like natural gas and electricity, and policies aimed at discouraging mangrove cutting (Lacerda et al., 1993; Naylor et al., 2002; Walters, 2003). Nonetheless, remote coastal communities in many parts of the tropics continue to depend heavily on mangrove wood for domestic fuelwood consumption, and commercial markets that sell mangrove charcoal to nearby towns and urban centers are not uncommon (Untawale, 1987; Walters and Burt, 1991; Alvarez-Leon, 1993; Allen et al., 2000; Dahdouh-Guebas et al., 2000b; Glaser, 2003).

The qualities of strength and durability (including pest- and rot-resistance) also make mangrove wood well-suited for use in construction (Adegbehin, 1993; Bandaranayake, 1998; Kairo et al., 2002; Walters, 2005a). Yet, the typically short and contorted growth form of tree stems of common genera such as Avicennia and Sonneratia renders them of limited value for large, commercial-sized lumber. The extraction of construction wood from mangroves is thus limited mostly to domestic consumption and sale of small-size posts to targeted local and regional markets (Fig. 1C). Mangrove wood is widely used in coastal communities for residential construction (posts, beams, roofing, fencing) and to make fish traps/weirs (Adegbehin, 1993; Alvarez-Leon, 1993; Rasolofo, 1997; Ewel et al., 1998a; Semesi, 1998; Kovacs, 1999; Primavera et al., 2004; Walters, 2004). Fronds from the mangrove "nipa" palm (Nypa fruticans (Thunb.) Wurmb.) are particularly valued in Southeast Asia for use in roofing and as thatch in walls and floor mats (Aksornkoae et al., 1986; Fong, 1992; Basit, 1995; Spalding et al., 1997; Walters, 2005a). Mangrove wood is also used in some countries for building boats, furniture, wharf pilings, telegraph poles, construction scaffolding, railway girders and mine timbers (Walsh, 1977; Mainoya et al., 1986; Adegbehin, 1993; Bandaranayake, 1998; Primavera et al., 2004; Lopez-Hoffman et al., 2006).

In addition to wood for fuel and construction, mangrove forest trees are also widely valued for their bark (used in tanning and dyes) 

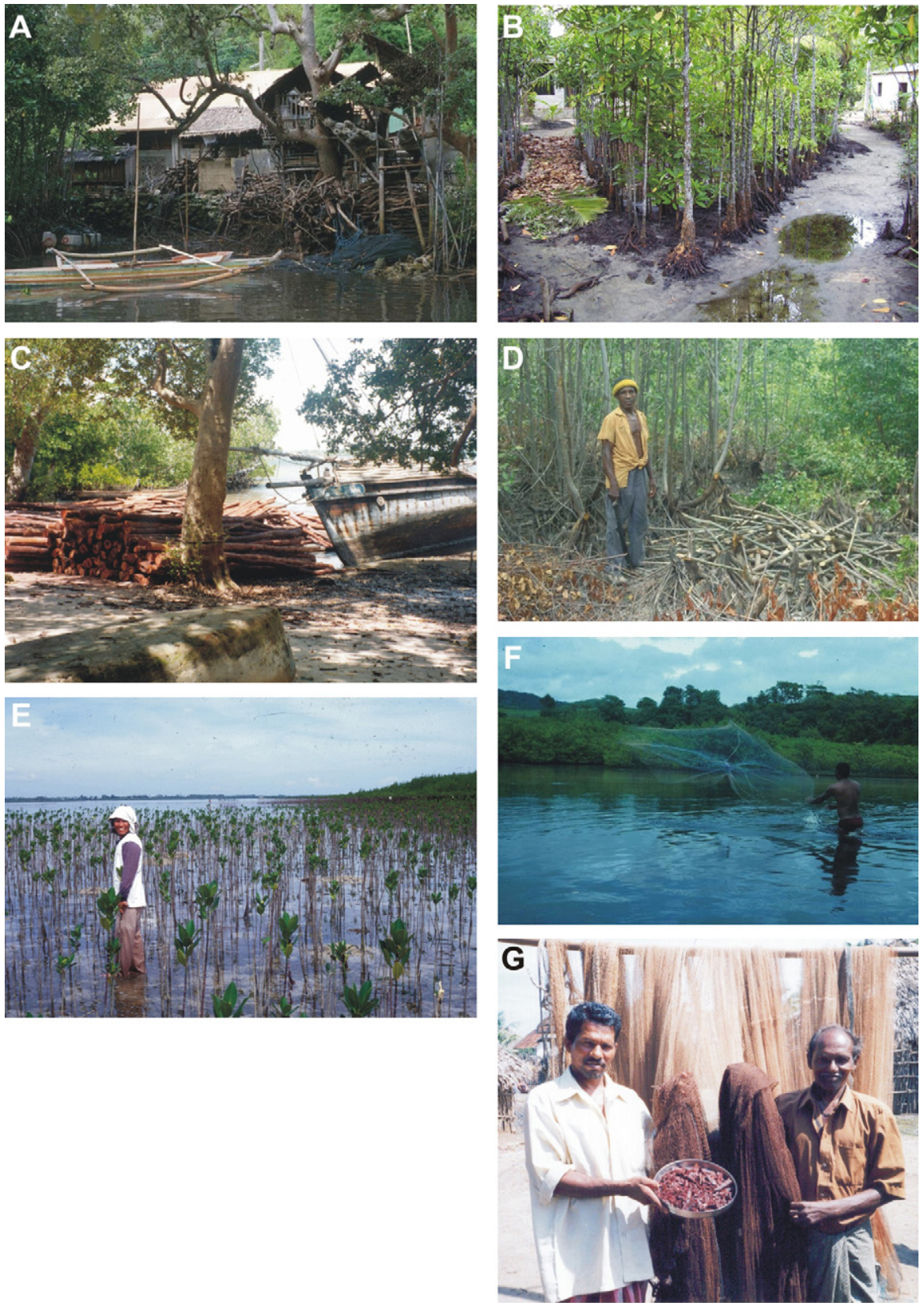

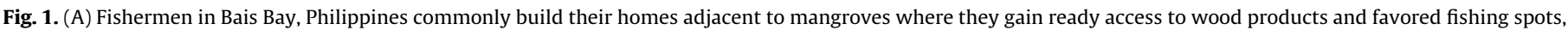

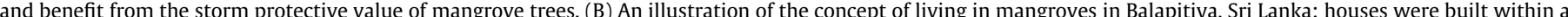

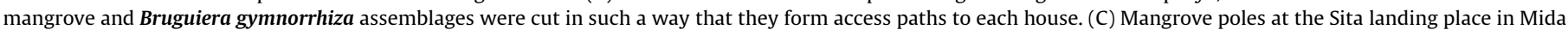

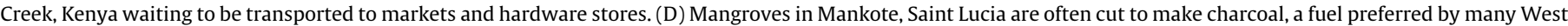

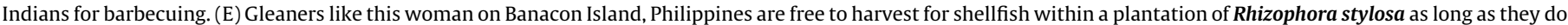

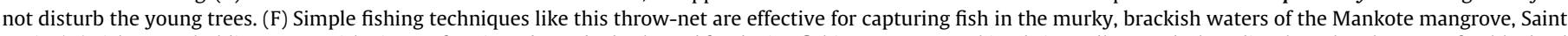

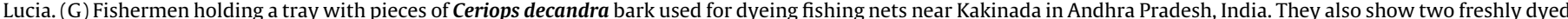

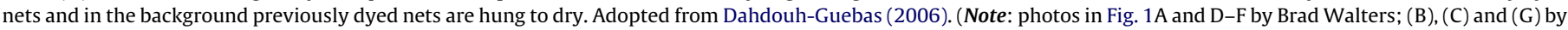
Farid Dahdouh-Guebas).

and wood fiber (to make rayon and paper); as sources of animal fodder, vegetable foods, and diverse traditional medicines and toxicants (see Bandaranayake, 1998, 2002 for a reviews); and as habitats for honey bees and hunted wildlife (see Table 1; Fig. 1G).

\subsection{Patterns and consequences of forest use}

Different mangrove species have different wood properties, making some more suitable than others for specific uses (FAO, 1994). For example, trees from the Rhizophoraceae family (Rhizophora, Ceriops, Bruguiera) are characterized by hard, dense wood that is rich in tannins and, as such, is widely valued for construction, fuelwood and tannin extraction, yet this wood is not suitable for lumber or furniture-making because of its tendency to split (Ewel et al., 1998a). Studies have documented mangrove wood harvesting that is size- and species-selective, and harvesters willing to venture widely in search of particular trees that are used in construction and have high local market value (Rasolofo, 1997; Dahdouh-Guebas et al., 2000b; Hauff et al., 2006).

However, despite differences in wood character and quality, research suggests that mangrove wood users are often flexible in their preferences, and willing to substitute favored mangrove 
Table 1

Summary of mangrove forest products and uses, with selected published references

Forest products and use

Wood for fuel (charcoal, firewood)

Wood for construction materials

Tree bark for tannins, dyes

Wood fiber for rayon, paper

Buds and leaves for vegetables, alcohol, livestock fodder

Plant parts and extracts for medicines, pesticides

Habitat for collecting honey, bees wax, and hunting wildlife
Selected references

See text

See text

Chapman, 1976; Aksornkoae et al., 1986; Mainoya et al., 1986; Lacerda et al., 1993;

Dahdouh-Guebas et al., 2000b; Primavera and de la Pena, 2000; Glaser, 2003

Christensen, 1982; FAO, 1985; Bhattacharyya, 1990; Ong, 1995; Bandaranayake, 1998; Ewel et al., 1998a

Morton, 1965; Walsh, 1977; Christensen, 1983b; Semesi, 1998; Dahdouh-Guebas et al., 2006a; Jayatissa et al., 2006

Sangdee, 1986; Chang and Peng, 1987; Bandaranayake, 1998, 2002; Sánchez et al., 2001; Primavera et al., 2004

Hamilton and Snedaker, 1984; Untawale, 1987; Adegbehin, 1993; FAO, 1994; Basit, 1995; Sathirathai and Barbier, 2001; Nagelkerken et al., 2008 species for less favored ones - or even non-mangrove species especially where the preferred wood has become less available or too costly to obtain (Walters, 2003). Harvest for fuelwood is often non-selective: some species are clearly better than others, especially for making charcoal, but evidence suggests people will harvest and burn as fuelwood almost any type of mangrove tree and are more likely to make decisions about which ones to harvest based on relative availability, rather than species preference (Walters, 2005a). In short, the material poverty of coastal communities and their widespread dependence on mangrove wood products to meet basic subsistence needs means users are often not in a good position to be selective and, instead, will harvest what is most readily available to them (Ewel et al., 1998a).

Patterns of harvest reflect the spatial distribution and relative accessibility of mangroves, which varies depending on local geomorphology and hydrology, socio-economic conditions, and past human disturbance (Ewel et al., 1998a; Hauff et al., 2006; Walters, 2003). Small-block clear-felling is applied, but to a limited extent and usually only in intensively managed forests (Hussain, 1995; Walters, 2004). Individual tree species vary dramatically in natural distribution within a mangrove and are often clumped in mono-specific stands. The dense above-ground root and branch growth of mangroves tends to make access to and clearing of forests difficult. These factors encourage the selective cutting of individual tree stems, branches and roots. To avoid such difficulties, pond construction in mangroves often starts with dike enclosures to retain water and kill the trees by flooding (for later clear-felling). It is also common for wood harvesting to concentrate on either the landward or seaward edges of a forest or along mangrove creeks, sites more readily accessible by foot during low tide or by boat during high tide (Walters, 2005a; Hauff et al., 2006; Lopez-Hoffman et al., 2006). Other things being equal, mangroves in proximity to human settlements are more likely to be heavily harvested. But whether and where mangroves are cut can also reflect the actions of government and coastal land owners who may restrict forest cutting. Yet, such restrictions may have limited effect on actual cutting practices given the practical difficulties of monitoring sites that are remote and simultaneously accessible by land and sea (Dahdouh-Guebas et al., 2000b, 2006a; Glaser, 2003; Walters, 2003, 2005a; Lopez-Hoffman et al., 2006).

Considerable research has been devoted to understanding the ecological effects of selection cutting and clear-felling as these treatments are applied in certain managed forests in Ecuador and South and Southeast Asia (Christensen, 1983a; FAO, 1985; Putz and Chan, 1986; Azariah et al., 1992; FAO, 1994; Nurkin, 1994; Blanchard and Prado, 1995; Hussain, 1995; Gong and Ong, 1995). But the relevance of this work is limited given that relatively little of the world's mangroves are subject to this kind of intensive forest management. In contrast, there has been remarkably little study of the ecological effects of informal, small-scale mangrove cutting by local coastal communities, a commonplace phenomenon that impacts mangroves in almost every region of the world.

Initial studies suggest that small-scale cutting typically involves the selective removal of one or few tree stems and/or branches at a time, causing localized structural disturbances that create relatively small gaps in the forest canopy (Smith and Berkes, 1993; Ewel et al., 1998b; Allen et al., 2001; Pinzon et al., 2003; Walters, 2005b). The creation of such gaps can alter microenvironmental conditions within the forest (Ewel et al., 1998b). Whereas clear-felling of mangroves tends to encourage regeneration of tree species that are better able to exploit large openings through seed dispersal and establishment, such as Rhizophora spp. and Bruguiera spp. (Putz and Chan, 1986; Blanchard and Prado, 1995; Hussain, 1995; Kairo et al., 2002; but see Azariah et al., 1992), the smaller openings created by selective cutting may better favor regeneration of species that successfully re-sprout/coppice from surviving stems, including Sonneratia spp., Avicennia spp., and Laguncularia racemosa (L.) Gaertn. f. (Smith and Berkes, 1993; Walters, 2005b; but see Pinzon et al., 2003). In contrast, the adult trees of Rhizophora, Ceriops and other genera of the Rhizophoraceae lack reserve meristems (Tomlinson, 1986), and therefore require replacement by new seedlings.

The cumulative effects of such selective cutting on a forest include reduced adult tree density, canopy height and canopy closure (Walters, 2005b; Hauff et al., 2006; Lopez-Hoffman et al., 2006). Heavily impacted stands are often characterized by few species of widely dispersed, dwarf-like trees manifesting a distinctly "bushy" appearance. Collateral damage from selective wood cutting may result in a net increase of dead wood in the forest (Allen et al., 2000). By contrast, local people in some settings intentionally forage for deadwood (for fuel) and thereby reduce levels of naturallyoccurring deadwood (Walters, 2005a). These various changes in forest structure, composition and micro-climate can significantly alter the habitat conditions for establishment of seedlings (Bosire et al., 2003, 2006) and for resident marine and terrestrial animals (e.g., Barnes, 2001; Bosire et al., 2004, 2005a, b; Crona and Rönnbäck, 2005; Crona et al., 2006; Crona and Rönnbäck, 2007).

\section{Mangrove-associated fisheries}

\subsection{Mangrove support functions to fisheries}

Fishery species that use mangroves as habitat can be classified into permanent residents, spending their entire life cycle in mangrove systems, temporary long-term residents, associated with mangroves during at least one stage in their life cycle, and temporary short-term residents or sporadic users of the mangrove habitat (Robertson and Duke, 1990b). The critical early life stages, i.e. the larvae and juveniles, of many fish and shellfish species utilize mangroves as nursery grounds, whereafter they emigrate to 
other systems such as coral reefs as adults (Matthes and Kapetsky, 1988; Robertson and Duke, 1990a; Ogden, 1997; Barletta-Bergan et al., 2002a, b; Nagelkerken et al., 2002; Crona and Rönnbäck, 2007; Serafy and Araújo, 2007). Through the abundance of early life stages, mangroves also attract carnivorous fishes that conduct feeding migrations to mangrove areas.

The postlarvae of many commercial penaeid shrimps enter mangrove-dominated environments, where they develop into juveniles and subadults before migrating back to sea to complete their life cycle (e.g., Dall et al., 1990; Chong et al., 1990, 1996; Vance et al., 1996; Primavera, 1998b; Rönnbäck et al., 1999, 2002). Mangrove mud crabs, sergestid shrimps, and giant freshwater prawn are other crustaceans of commercial value that utilize mangroves as habitat during some life stage. Highly valued food and game fish that have a close association with mangroves include groupers, snappers, sea-perch, mullets, catfishes, milkfish, and tarpons. Mangroves also support many mollusk species that constitute an important in situ fishery. Edible species of oysters, mussels, cockles, and gastropods are collected extensively for local consumption, usually by the families of local fishermen, and/or market sale, e.g., the mangrove clam Anodontia edentula Linn. (Primavera et al., 2002). For more detailed information on fish and invertebrates associated with mangrove environments see Macintosh (1982), Rönnbäck (1999), and the biogeographic analysis by Matthes and Kapetsky (1988).

Mangroves also indirectly support fisheries where the harvested species never enter mangrove environments. Mangroves, seagrass beds, unvegetated shallows, and coral reefs can exist in isolation from each other, but commonly form integrated ecosystems of high productivity (Yanez-Arancibia et al., 1993: Ogden, 1997; Rönnbäck, 1999). For example, the ability of mangroves to control water quality (trapping and assimilating sediment and nutrients) is a prerequisite for coral reef functioning, including fisheries production (Kühlmann, 1988).

Another indirect support function to fisheries is the bioeconomics of shrimp trawling. Penaeid shrimps, which dominate global shrimp catches, are one of the most important fishery resources worldwide in terms of volume of catch and value per unit catch (Dall et al., 1990). Because penaeid shrimp sales generate most of the revenues from mechanized trawling in developing countries, shrimps (and indirectly their nursery habitat, i.e. mangroves) effectively subsidize commercial fish harvesting efforts by these vessels, including fish species not using mangroves as habitat (Turner, 1977; Bennett and Reynolds, 1993; Rönnbäck, 1999). Trawl catch ratio between marketed fish and penaeids in Indonesia was $667 \mathrm{~kg}$ of fish for every $100 \mathrm{~kg}$ of shrimps trawled (Turner, 1977).

Apart from fisheries aimed directly for human consumption, mangroves also support aquaculture operations by providing seed, broodstock and feed inputs (Rönnbäck, 1999; Naylor et al., 2000). Mangroves function as nursery grounds for the early life stages of aquaculture species like penaeid shrimps, mangrove mudcrabs, sea-perch, snapper, grouper, milkfish, etc. (Matthes and Kapetsky, 1988; Bagarinao, 1994; Primavera, 1998b; Walton et al., 2006a; Cannicci et al., 2008; Nagelkerken et al., 2008). The collection of wild seed, which supports major fishery operations in many countries, has however been criticized for bycatch problems. For example, the tiger prawn (Penaeus monodon Fabricius), which dominates shrimp aquaculture production, constitutes a very small proportion (down to $0.1 \%$ ) of fish and invertebrate larvae in seed collector's catch (reviewed by Primavera, 1998a). This bycatch is usually sorted out on land and not returned to the sea, which could have significant negative impacts on biodiversity and capture fisheries production in the area. Some countries have developed hatcheries for seed production of cultured species. This may have reduced the dependence on mangroves to produce wild seed, but has increased demand for wild-caught broodstock instead. For instance, penaeid shrimp hatcheries often rely on the continuous input of mature females to sustain productivity as well as to avoid inbreeding problems. The mangroves in the Godavari delta, India, have been estimated to support an annual catch around 50,000 tiger prawn (Penaeus monodon) spawners, valued at US\$ 6 million (Rönnbäck et al., 2003).

Mangroves and aquaculture are not necessarily incompatible. Already, the culture of seaweeds, mollusks and fish in cages in subtidal waterways is both compatible with mangroves and amenable to small-scale, family-level operations (Primavera, 1993, 1995). But there remains a need for mangrove-friendly aquaculture technology in the intertidal forest or swamp that does not require clearing of the trees. Development of such technology is on two levels: (a) silvofisheries or aquasilviculture where the lowdensity culture of crabs and fish is integrated with mangroves and (b) mangrove filters where adjacent mangrove stands are used to absorb effluents from high-density shrimp and fish culture ponds (Primavera, 2000b; Primavera et al., 2007). Present-day versions of integrated forestry-fisheries-aquaculture can be found in the traditional gei wai ponds in Hong Kong, mangrove-shrimp ponds in Vietnam, aquasilviculture in the Philippines, and silvofisheries in Indonesia (Primavera, 2000b). The Southeast Asian Fisheries Development Center Aquaculture Department has recently put out guidelines for sustainable aquaculture in mangrove ecosystems (Bagarinao and Primavera, 2005).

\subsection{Economic importance of mangrove-associated fisheries}

Fisheries production constitutes the major value of marketed natural resources from mangrove ecosystems. In terms of habitat use, the mangrove support to commercial, recreational and subsistence fisheries is well documented (see review in Rönnbäck, 1999). For instance, $80 \%$ of all marine species of commercial or recreational value in Florida, USA, have been estimated to depend upon mangrove estuarine areas for at least some stage in their life cycles (Hamilton and Snedaker, 1984). The relative contribution of mangrove-related species to total fisheries catch can also be significant, constituting $67 \%$ of the entire commercial catch in eastern Australia (Hamilton and Snedaker, 1984), 49\% of the demersal fish resources in the southern Malacca Strait (Macintosh, 1982), $30 \%$ of the fish catch and almost $100 \%$ of shrimp catch in ASEAN countries (Singh et al., 1994).

Non-marketed catch is never included in fishery statistics, although coastal subsistence economies in many developing countries harvest substantial amounts of fish and shellfish from mangroves (Fig. 1F). The contribution of subsistence fisheries to total catch supported by mangroves was estimated at $10-20 \%$ in Sarawak (Bennett and Reynolds, 1993), 56\% in Fiji (Lal, 1990), and 90\% in Kosrae (Naylor and Drew, 1998). The annual subsistence harvest per household has been valued at US\$610 in Fiji (Lal, 1990) and $\$ 900$ in Irian Jaya, Indonesia (Ruitenbeek, 1994). For the poorest coastal families, mangrove fisheries clearly have an emergency food provision function and constitute the main source of protein in their diet (Magalhaes et al., 2007).

The most frequently used method to assess the mangrove support to commercial fisheries is the production function approach, where mangroves are put in as a determinant for fisheries catch (Barbier, 1994, 2003). Positive correlations between offshore yield of penaeid shrimps and amount of mangrove forest in the nursery area have been demonstrated throughout the tropics (e.g., Turner, 1977; Pauly and Ingles, 1986; Baran and Hambrey, 1998; Lee, 2004), whereas studies on other crustaceans, fish and molluscs are scarce (Rönnbäck, 1999). Correlations have been found between penaeid catches and latitude (inversely 
proportional) by Turner (1977) and Pauly and Ingles (1986), and with extent of intertidal areas and tidal amplitude (Lee, 2004). Furthermore, Pauly and Ingles (1986) found a non-linear logarithmic relationship between mangrove area and penaeid shrimp production, implying that the shrimp fisheries impact of reducing mangrove area becomes greater as the remaining area is reduced. Similarly, the length of mangrove-lined estuary or habitat edge where juvenile prawns have access to the mangrove is a more important indicator of shrimp densities than total area per se (Staples et al., 1985; Chong, 2007).

Quantitative estimates of fisheries production supported by mangroves have mainly focused on penaeid shrimps (e.g., Christensen, 1982; Lal, 1990; Ruitenbeek, 1994; Barbier and Strand, 1998), and there is a severe lack of productivity and monetary estimates for other fisheries (Nickerson, 1999; Rönnbäck, 1999). This may be related to the varying degree of mangrove importance as nurseries for fish, especially in the presence of alternative habitats like seagrass beds (Robertson and Duke, 1990a; Nagelkerken et al., 2000, 2002; Nagelkerken and van der Velde, 2004). To identify and value total commercial and subsistence fisheries catch supported by mangroves, economic analyses must take into account: (1) the large number of resident and transient species that utilize mangroves as habitat; (2) the biophysical interactions in the coastal seascape biome; (3) the direct and indirect subsidies of shrimp trawlers and mangroves, respectively, to total fisheries catch; and (4) the aquaculture industry's dependence on inputs like seed, broodstock and feed (Rönnbäck, 1999). By acknowledging these support functions, the potential life-support value of mangroves to fisheries is in the order of 1-10 tons of fish and shellfish per ha and year (first sale value $\approx 1000-10,000$ US\$ in developing countries) (Rönnbäck, 1999).

\section{Mangrove ecosystem services}

Mangroves support a wide variety of ecosystem services (e.g., Saenger et al., 1983; Ewel et al., 1998a; Moberg and Rönnbäck, 2003; Barbier, 2007; Rönnbäck et al., 2007a), which can be classified into supporting, provisioning, regulating and cultural services (Millennium Ecosystem Assessment, 2005). Supporting services are those that are necessary for all other ecosystem services, and include soil formation, photosynthesis, primary production, nutrient cycling and water cycling. Provisioning services are the natural products generated by mangroves (see previous sections).

Regulating ecosystem services are the benefits obtained from the regulation of ecosystem processes such as resilience, pollination, biological control, nutrient cycling, air quality regulation, and maintenance of biodiversity for ecosystem function and resilience, etc. (Millennium Ecosystem Assessment, 2005; Rönnbäck et al., 2007b; Bosire et al., 2008; Cannicci et al., 2008; Gilman et al., 2008; Kristensen et al., 2008; Nagelkerken et al., 2008). Regulating services analyzed in detail below include water quality maintenance, environmental disturbance prevention (storm, flood and erosion control) and climate regulation. One critical function supporting all these services is that mangroves effectively retard water flow, mainly as a function of the trees' three-dimensional structural complexity and the complex topographical features of channels, creeks, etc. This enables efficient trapping of suspended and particulate matter, which can lead to land accretion buffering against potential sea level rise in the future.

Favorable sediment characteristics and high photosynthetic rates of many mangrove systems provide the basis for the biofilter function with high nutrient uptake levels (Rivera-Monroy et al., 1995; Robertson and Phillips, 1995; Alongi et al., 2000). Peri-urban coastal areas of the developing world receive extensive amounts of untreated sewage, and mangroves certainly filter this discharged wastewater, thereby limiting coastal sewage pollution. Based on the cost of constructing a sewage treatment plant, the value of biofilter functions of mangroves has been estimated at US\$ $1193 \mathrm{ha}^{-1}$ year $^{-1}$ to US\$ $5820 \mathrm{ha}^{-1}$ year $^{-1}$ depending on types and extent of mangroves (Table 2). The wide-scale conversion of mangroves to accommodate shrimp farms removes the natural biofilter function of surrounding mangroves. Consequently, waste laden pond effluent water is reused causing self-pollution (Rönnbäck, 1999; Kautsky et al., 2000) in the farm system itself, but also affecting remaining mangroves and littoral habitats, often of primary importance for collection of marine products by local communities. Robertson and Phillips (1995) estimated that up to 22 ha of mangrove forest would be required to filter the nutrient load per hectare of intensive shrimp pond. More recently, Primavera et al. (2007) showed that 1.8-5.4 ha of mangroves are required to remove nitrates in effluents from 1 ha of shrimp pond.

Mangroves are considered as a natural barrier protecting the lives and property of coastal communities from storms and cyclones, flooding, and coastal soil erosion (Farber, 1987; Othman, 1994; Sathirathai and Barbier, 2001; Lal, 2002; Walters, 2003, 2004; Badola and Hussain, 2005; Hong, 2006; Barbier, 2007). Values ascribed to this service include, for example, US\$120 per household (Badola and Hussain, 2005), and US\$ $3700 \mathrm{ha}^{-1}$ (Sathirathai and Barbier, 2001) and US\$ $4700 \mathrm{ha}^{-1}$ (Costanza et al., 1989) of mangrove (Table 2). These are major indirect benefits and a principal reason for planting mangroves along many low-lying coasts. Artificial structures to replace the coastal protection services provided by mangroves can be expensive (Moberg and Rönnbäck, 2003; Walters, 2003) and may not be as effective (Badola and Hussain, 2005; Barbier, 2006).

In particular, the Indian Ocean Tsunami disaster of December 26, 2004 , which killed over 200,000 people and damaged livelihoods and coastal resources in 14 Asian and African countries, highlighted the role of protection and sound management of the coastal environment and provided a stark reminder that environmental sustainability and human security are inseparable (Walters, 2006).

The tsunami disaster has received scientific and media attention worldwide, and the protective function of mangroves for landward human settlements has been often highlighted. Yet, most reports with respect to protection by mangrove forests were either very localized and/or anecdotal in nature (Danielsen et al., 2005; Harakunarak and Aksornkoae, 2005; IUCN, 2005; Liu et al., 2005; Roy and Krishnan, 2005; Williams, 2005; Dahdouh-Guebas, 2006; Stone, 2006; Wells and Kapos, 2006). This has prompted two, contradicting 'narratives' among authors and policy-makers regarding the protective role of mangroves. On one hand, some have generalised the protective function of mangroves as documented from some areas to entire coastlines and countries and therefore over-interpreted the role of mangroves. On the other hand, others have generalised the apocalyptical nature of a tsunami based on the Banda Aceh experience and minimalised the role of mangroves to the extent of suggesting that they are ineffective and that more effort should be focused on tsunami alert systems (Overdorf and Unmacht, 2005; Baird, 2006). Both views have been criticized because of insufficient examination of results or assumptions supporting this function (Dahdouh-Guebas et al., 2005c; Kathiresan and Rajendran, 2005; Dahdouh-Guebas and Koedam, 2006).

The role of mangroves in wave attenuation has long been scientifically proven (Furukawa et al., 1997; Wolanski, 1995; Mazda et al., 1997; Massel et al., 1999). Reduction of waves depends on water depth, wave period and height, quality of the mangrove forest, and type of aerial root systems (Mazda et al., 1997; Kathiresan, 2003; Dahdouh-Guebas et al., 2005c). The post tsunami studies have found that human deaths and loss of property was a function of type and area of the coastal vegetation shielding the villages (Dahdouh-Guebas et al., 2005c; Kathiresan 
and Rajendran, 2005; but see Kerr and Baird, 2007). Further evidence of the storm protective value of mangroves can be found in studies of local peoples' knowledge and practices. Among some coastal communities in the Philippines and India there is a widelyheld appreciation for the storm protective function of mangroves, and many people plant and protect mangrove trees explicitly for this purpose (Fig. 1A; Walters, 2003, 2004; Badola and Hussain, 2005; Walton et al., 2006b). It is common practice for small-boat fishers in these countries to seek the shelter of mangroves during storms, but sheltering in deep mangrove creeks also provided protection to commercial, recreational and naval vessels in the port of Cairns, Australia when tropical cyclone Larry crossed the Queensland coast on 20 March 2006 (Williams et al., 2007). Some earlier studies have also suggested that the loss of lives due to hurricanes, tidal waves, typhoons, etc. could have been reduced by the presence of a mangrove protective belt (Fosberg, 1971; Primavera, 1995; Mazda et al., 1997; Massel et al., 1999).

Mangrove ecosystems are among the most productive and biogeochemically active ecosystems and represent potentially important sinks of carbon in the biosphere (Twilley et al., 1992; Ong, 1993; Gattuso et al., 1998). Clough et al. (1997) calculated net photosynthetic rates of $155 \mathrm{~kg} \mathrm{Cha}^{-1}$ per day in a 22-year old Rhizophora apiculata Bl. forest in Malaysia (Table 2). The carbon stock per unit area can also be enormous as the top layers of mangrove sediments store large amounts of organic carbon, typically an order of magnitude higher than those of other tropical forests. Successful management of mangrove ecosystems thus has the potential to produce a 'measurable' gain in $\mathrm{CO}_{2}$ sequestration (Ayukai, 1998), a characteristic likely to acquire greater attention with the forecasted global warming this century.

Cultural services stem from dynamic and complex social attributes. The variety within coastal ecosystems provides humans with almost unlimited opportunities for aesthetic and recreational experiences, cultural and artistic inspiration, as well as spiritual and religious enrichment (Fig. 1B; Mastaller, 1997; Kaplowitz, 2001; Rist and Dahdouh-Guebas, 2006; Rönnbäck et al., 2007b). An intriguing illustration comes from the Asmat from Irian Jaya, Indonesia, who have largely preserved their traditions and beliefs (Mastaller, 1997). According to their legends, their creator carved human-like figurines out of a mangrove root which came to life when he played a selfmade drum out of a mangrove tree (loc. cit.). Today, Rhizophora roots are still used to carve mystic totem poles (loc. cit.).

The location of mangroves along the coastline, often proximate to populated areas, combined with their unique ecological and aesthetic character, affords opportunities for development of ecotourism and environmental education. Many coastal communities have co-evolved with their local mangrove ecosystems. Their traditional use of mangrove resources is often intimately connected with the health and functioning of the system. These uses are often governed by customary rights, traditions and heritage, and they are often closely tied to the culture of the local communities. The failure to recognize these customary use rights has often resulted in the alienation of local communities in managing local mangrove ecosystems, and in participating in the replanting and rehabilitation of mangroves (Walters, 2004; Barbier, 2006), subsequently undermining incentives for, and use of, LEK which could be valuable for management purposes.

\section{Mangrove management, planning and policy}

\subsection{Property rights, resource access and conflict}

Mangroves are unusual environments in that they are located between dry land and shallow marine and brackish water. This characteristic introduces complexities to planning and manage- ment because of competing and overlapping interests in mangrove lands and their resources. In short, mangroves are valuable coastal lands to various forest users and land developers, each one having incentive to claim and control access through degrees of privatization. But this tenure dynamic changes because marine and estuarine waters in mangroves as elsewhere are typically viewed as open access transportation corridors for fishing boats, and the diverse fish and crustaceans within these waters are usually treated as a common property resource available for harvest by local fishermen.

These complexities are often mirrored in government policy. Until recently, most governments considered mangroves to be relatively worthless swamplands, so rational policy guiding their management has in most cases been late in coming. Being part land and part sea, jurisdictional ambiguities are often present. For example, regulation of mangrove forest lands in the Philippines has historically fallen under the legal jurisdiction of both the Department of Environment and Natural Resources (formerly the Ministry of Forests), whose mandate was to protect and sustainably manage these as forests, and the Department of Agriculture, whose mandate was to promote brackish water aquaculture development in these same areas (Primavera, 2000a, 2005; Walters, 2003). Thus, government decisions concerning mangroves were often made with ". . . the right hand not knowing what the left hand was doing" (Primavera, 1993, p. 168). Similar problems of jurisdictional ambiguity over mangroves have been documented in Ecuador (Meltzoff and LiPuma, 1986), India (Bhatta and Bhat, 1998; Dahdouh-Guebas et al., 2006a), Thailand (Vandergeest et al., 1999), Sri Lanka (Dahdouh-Guebas et al., 2000a, b), Indonesia (Armitage, 2002) and Brazil (Glaser and Oliveira, 2004).

But such ambiguities go beyond government policy and affect informal understandings and customary rules concerning access and use of mangroves by different users. Customary use of mangroves is typically characterized by common access rights, with different uses overlapping but to a large degree accommodating one another (Fig. 1E; Bhatta and Bhat, 1998; Walters, 2004). Conflict in such situations can arise, for example, where customary boat access or seine fishing rights become impaired by the construction of a dyke or the planting of mangrove trees (Walters, 2004), or where resident mangrove fishers and wood users are forced to compete with outsiders for the same resources (Glaser and Oliveira, 2004). The potential for such conflict is exacerbated where large tracts of mangrove are leased to private interests who displace common access users (Bailey, 1988; Dewalt et al., 1996; Stonich and Bailey, 2000; Walters, 2003, 2004; Hoq, 2007). The issue of shrimp farming is particularly problematic because the large profit potential of these operations creates incentive for corruption of legal mechanisms that might otherwise protect the forests and/or interests of local users (Meltzoff and LiPuma, 1986; Bhatta and Bhat, 1998; Stonich and Vandergeest, 2001; Armitage, 2002; Dahdouh-Guebas et al., 2002). In short, conflict is more likely to emerge in the absence of shared understandings about rules of access, clear government regulations, and effective means of enforcement and dispute resolution.

\subsection{Deforestation and competing land uses}

Mangrove forests are among the most threatened global ecosystems, especially in Asia, and current mangrove area has fallen below 15 million hectares, down from 19.8 million ha in 1980 (Wilkie and Fortuna, 2003). Global rates of loss in the past two decades vary from 20\% (Wilkie and Fortuna, 2003) to $35 \%$ (Valiela et al., 2001). The average rate of $1.52 \%$ mangroves lost per year (Valiela et al., 2001; Alongi, 2002) shows an improvement from $1.9 \%$ in the 1980 s to $1.1 \%$ in the 1990 s (Wilkie and Fortuna, 
Table 2

Examples of economic assessments of some regulating ecosystem services supported by mangroves

\begin{tabular}{|c|c|c|}
\hline Regulating service & Values and benefits & Reference \\
\hline Water quality maintenance (biofilter function) & $\begin{array}{l}\text { US\$ } 5820 \text { ha }^{-1} \text { year }^{-1} \\
\text { US } \$ 1193 \text { ha }^{-1} \text { year }^{-1} \\
7.4 \text { and } 21.6 \text { ha of mangroves needed to remove } \\
\text { nitrate and phosphorous, respectively, in effluents } \\
\text { per ha of intensive shrimp pond } \\
1.8-5.4 \text { ha of mangroves needed to remove nitrate } \\
\text { in effluents per ha of shrimp pond }\end{array}$ & $\begin{array}{l}\text { Lal, } 1990 \\
\text { Cabrera et al., } 1998 \\
\text { Robertson and Phillips, } 1995 \\
\text { Primavera et al., } 2007\end{array}$ \\
\hline $\begin{array}{l}\text { Environmental disturbance prevention } \\
\text { (storm, flood and erosion control) }\end{array}$ & $\begin{array}{l}\text { US\$ } 4700 \text { ha }^{-1} \\
\text { US\$ } 3679 \text { ha }^{-1} \\
\text { US\$ } 120 \text { per household }\end{array}$ & $\begin{array}{l}\text { Costanza et al., } 1989 \\
\text { Sathirathai and Barbier, } 2001 \\
\text { Badola and Hussain, } 2005\end{array}$ \\
\hline Carbon sink & $\begin{array}{l}155 \mathrm{kgC} \mathrm{ha}^{-1} \text { day }^{-1} \\
1500 \mathrm{~kg} \mathrm{C} \mathrm{ha}^{-1}\end{array}$ & $\begin{array}{l}\text { Clough et al., } 1997 \\
\text { Ong, } 1993\end{array}$ \\
\hline
\end{tabular}

2003). Nevertheless, the prospect of a world without mangroves appears to be real (Duke et al., 2007). Although many factors are behind global mangrove deforestation, a major cause is aquaculture expansion in coastal areas, especially the establishment of brackish water fish and shrimp farms (Primavera, 1995; Barbier and Cox, 2003). Aquaculture accounts for $52 \%$ of mangrove loss globally, with shrimp farming alone accounting for $38 \%$ of mangrove deforestation; in Asia, aquaculture contributes $58 \%$ to mangrove loss with shrimp farming accounting for $41 \%$ of total deforestation (see Table 3 in Valiela et al., 2001). Other factors in mangrove decline are forest use, mainly for industrial lumber and woodchip operations (26\%), freshwater diversion (11\%), and reclamation of land for other uses (5\%). The remaining causes of mangrove deforestation are herbicide impacts, agriculture, salt ponds and other coastal developments. A global survey of 38 coastal, island and estuarine mangrove stands confirmed that clear cutting and reclamation for agriculture and aquaculture, urban expansion and resort development threatened the majority (55\%) of all sites visited (Farnsworth and Ellison, 1997).

The conversion of mangroves to aquaculture ponds has been fuelled by governmental support, private sector investment and external assistance from multilateral development agencies such as the World Bank and Asian Development Bank (Siddall et al., 1985; Verheugt et al., 1991). To quote a report of the 1978 Aquaculture Project in Thailand "The subproject will involve the large-scale development of mangrove swamps into small shrimp/ fish pond holdings ..." (ADB, 1978 in Primavera, 1998a). From US $\$ 368$ million (representing only $14.1 \%$ of total fisheries assistance) in 1978-1984, international aid to aquaculture increased to $\$ 910$ million (33.7\% of total fisheries assistance) in 1988-1993 (Primavera, 1998a). The Asian Development Bank alone provided total aid to fisheries and aquaculture of $\$ 1085$ million in the 19691996 period, including US $\$ 21.8$ million in aquaculture loans for shrimp and milkfish ponds and hatcheries in the Philippines (Primavera, 1998a, 2000b). But the much earlier fishpond boom of the 1950s was fuelled by a loan of US\$23.6 million for fishpond construction and operations from the International Bank for Reconstruction and Development intended "to accelerate ... the conversion of vast areas of marshy lands [mangroves] ... into productive fishponds" (Villaluz, 1953, in Primavera, 2000a).

The effects of this decline in mangrove area are exacerbated by the widespread degradation of remaining forests, the result of over-cutting of wood and over-harvesting of mangrove aquatic resources. The extent of such degradation is not well documented, but case studies reveal dramatic changes to the structure and composition of harvested forests and associated declines in resource availability to local communities (Kairo et al., 2002; Walters, 2005b). Infrastructure developments and upland land use can cause sedimentation and changes to hydrology that impact mangroves at some distance, causing the gradual die-back of particular species or entire stands (Dahdouh-Guebas et al., 2005b). Ironically, such ecological degradation can be masked by the expansion of less typical, less functional and less vulnerable species and thus take the form of 'cryptic ecological degradation' (sensu Dahdouh-Guebas et al., 2005b).

Problems of deforestation and degradation are compounded by growing human populations in many coastal areas (Primavera, 2000a). The Philippines offers a case in point: mangroves once abundant around Manila Bay at the turn of the last century have since been entirely cleared, the combined result of fish pond development, urban infrastructure expansion and residential spread (Brown and Fischer, 1918; Cabahug et al., 1986). Similarly, in a more rural region of the country, Bais Bay, mangroves have declined in area over the past 50 years by $75 \%$ at the same time that coastal populations have increased 10-fold (Walters, 2003). Population growth coinciding with declining mangrove area has likewise been documented along the coastlines of Honduras (Dewalt et al., 1996), Vietnam (de Graaf and Xuan, 1998) and Bangladesh (Bashirullah et al., 1989).

\subsection{Mangrove silviculture}

Mangrove silviculture has been practiced in some Asian countries since the 19th century (Brown and Fischer, 1918; Watson, 1928; Curtis, 1933; Hussain and Ahmed, 1994; Kaly and Jones, 1998; Vannucci, 2002). Mangroves are planted for various purposes, including (i) wood production to support commercial or small-scale forestry; (ii) shoreline protection, channel stabilization and storm protection for coastal human settlements from cyclones and other extreme natural events, and for protection against seawater intrusion; (iii) fisheries, aquaculture and wildlife enhancement; (iv) legislative compliance with protective measures and compensatory requirements; (v) social enrichment (e.g., aesthetics, income generation through eco-tourism); and (vi) ecological restoration (Field, 1996; Bhatta and Bhat, 1998; Kairo et al., 2001; Walters, 2004; Walters et al., 2005). Nursery and planting techniques vary considerably among mangrove species, and the silvicultural methods chosen will depend on which of the above objectives are desired (Field, 1998; Saenger, 2002).

Traditionally, both clear-felling and selection systems have been used, and in some areas a mixed system has been employed (FAO, 1994). Clear-felling systems applied to mangrove forests are the most cost-effective, although erosion and site deterioration risks as well as the loss of ecosystem services are higher. Clearfelling has been found suitable for some economically valuable species, such as Rhizophora apiculata, R. mucronata Lamk. and 
$R$. stylosa Griff., which are strong and light-demanding and so can withstand competition in open areas. In selection systems, the stands are uneven-aged and the forest cover is never completely removed. They are more environment-friendly since marketable trees are harvested periodically and over all parts of the forests, providing better soil protection and biodiversity, reducing risks of insect damage and invasions, and offering improved wind buffering. However, selection systems are less cost-effective due to their complexity and greater labor requirements.

Mangrove silvicultural practices have produced mixed results depending on the practices. For example, the success of mangrove management since the beginning of the 20th century in Matang, Malaysia is mainly due to intensive reforestation efforts (Ong, 1995; Chan, 1996), although decline in yields has been reported since the late 1960s (Gong et al., 1980; Gong and Ong, 1995). Likewise, multi-use managed forests in the Sunderbans have maintained long-term productivity through the application of scientific silvicultural practices with traditional knowledge (Vannucci, 2002). In Venezuela, however, the Guarapiche Forest Reserve, San Juan River is yet to recover fully despite well-planned silvicultural practices (Lacerda et al., 2002). Although restored mangrove forests may resemble forest plantations rather than natural forests, such plantations can be a first step toward mangrove rehabilitation (Ellison, 2000; Bosire et al., 2003; Bosire et al., 2008; but see Walters, 2000). To improve the success in rehabilitation, other silvicultural methods have been employed including natural regeneration, assisted regeneration and macropropagation.

Reforestation of mangrove forests through natural regeneration is relatively inexpensive and maintenance is less labor-intensive. Natural regeneration leads to better early root development and causes less soil disturbance. However, the success of natural regeneration will depend on the state of degradation of the original mangrove. Although assisted regeneration is more expensive, its costs will vary depending on labor costs, site characteristics, proximity to propagule sources, and whether propagules, seedlings or transplants are used (Saenger, 1996). Assisted regeneration may be required at sites with insufficient natural regeneration. Approaches for macro-propagation of mangroves include direct planting of propagules collected from the wild, out-planting of up to 1-year-old nursery-raised propagules, direct transplanting of seedlings and shrubs, out-planting after nursery-raising small seedlings collected from the wild, raising of air-layered material, and use of stem cuttings (Carlton and Moffler, 1978; Hamilton and Snedaker, 1984; Field, 1996).

\subsection{Ecological restoration}

Ecosystem restoration to the original pristine state, or rehabilitation to recover some ecosystem functions, may be appropriate when a mangrove ecosystem has been altered so that normal processes of secondary succession or natural recovery from damage are inhibited in some way. Mangrove restoration is increasingly practiced in many parts of the world (Ellison, 2000; Kairo et al., 2001; Vannucci, 2002). Mangrove forests have been rehabilitated to achieve a variety of goals, e.g., for commercial purposes (Watson, 1928), restoring fisheries and wildlife habitat (Lewis, 1992; Stevenson et al., 1999), multiple community use purposes, or shoreline protection purposes (Thorhaug, 1990; Saenger and Siddiqi, 1993; Bhatta and Bhat, 1998; Field, 1998; Walters, 2004; Barbier, 2006; Walton et al., 2006b).

There is already a great deal of knowledge and experience in rehabilitating mangroves by artificial means around the world (Field, 1996, 1998). However, many of these efforts are carried out without considering the experience and lessons learned from similar projects, resulting in duplication of efforts and waste of resources (Elster, 2000; Kairo et al., 2001). Recently, interest has focused on indigenous or folk technologies for mangrove restoration. For example, local fisherfolk have been planting mangroves in some areas of Southeast Asia for decades, well before governments and non-government organizations began to promote the activity as a conservation tool (Fig. 1E; Fong, 1992; Weinstock, 1994; Walters, 2000, 2004). These local management systems are relatively small-scale and utilize simple technologies, but they can be rich in knowledge and practical experience that is usually overlooked by "experts" who promote mangrove reforestation (Vayda et al., 2004; Walters, 1997; Walters et al., 2005).

Failure to better understand the local environmental and socio-economic contexts of mangrove restoration dooms many such efforts. Mangrove restoration projects often have moved immediately into planting of mangroves without determining the cause of previous degradation or why natural recovery has failed (Lewis, 2000, 2005). Even where environmental conditions permit natural or assisted restoration of a site, ongoing or future disturbance of the area by local people may prevent it (Walters, 1997). Ideally, mangrove restoration success should be measured as the degree to which the functional replacement of natural ecosystem has been achieved. However, long-term success in mangrove replanting will be determined by the level of support and involvement of local communities and local governments (Primavera and Agbayani, 1997; Walters, 1997, 2004; Lewis, 2000; Barbier, 2006). Mangrove rehabilitation programs that only utilize coastal communities as sources of replanting labor and do not involve them in the long-run management of the various uses of the restored ecosystem are less likely to be successful (Rönnbäck et al., 2007a).

A review of mangrove (re)planting in the Philippines over the past century shows a change from community-led efforts to projects externally driven by international development grants and loans. This change in drivers is paralleled by an increase in planting costs from $<\$ 100 \mathrm{ha}^{-1}$ to over $\$ 500 \mathrm{ha}^{-1}$, yet long-term survival rates generally remain low. Poor survival can be traced to inappropriate species (Rhizophora is favored over the natural colonizers Avicennia and Sonneratia because it is easier to plant), and unsuitable sites in open access but suboptimal lower intertidal to subtidal zones, rather than the ideal but contentious middle to upper intertidal areas which have long been converted to aquaculture ponds. For mangrove rehabilitation efforts to succeed, funding appears to be of secondary importance relative to suitable sites and species, community involvement and commitment, and grant of tenure.

\subsection{Geo-spatial monitoring and analysis}

In order to develop and implement effective policy regarding the socio-economic use of mangrove forests, it is essential that stakeholders have access to accurate and cost-effective techniques for mapping and monitoring these coastal wetlands. Given that many of these forests are quite large, are located in remote areas and have been experiencing rapid changes, it is not surprising that various remote sensing techniques have been employed to determine their spatial distribution and health. Traditional aerial photography is still being employed (e.g., Krause et al., 2004; Dahdouh-Guebas et al., 2006b) to map these forests, but given their repetitive coverage with constant image quality and immediate ease of operation, the use of satellite imagery, both optical and radar, now govern this endeavor. Satellite imagery enables resource managers to quickly map and continuously monitor their mangroves without the constant need for exhaustive field surveys. Using very high resolution imagery, the development 
of single species or even trees can be monitored, which may be necessary in light of selective cutting and ecological degradation (Dahdouh-Guebas et al., 2005a). Moreover, these digital data are easily transferable into Geographic Information Systems for spatial analyses studies at a broader coastal management level.

There are two types of space-borne data available for mangrove forest mapping, optical and radar. Optical sensors rely on reflected sunlight, primarily in the visible and infra-red regions of the electromagnetic spectrum. With regards to mangroves, the signals received can provide information regarding the photosynthetic activity of the trees which can then be used to distinguish them from other non-mangrove land covers or even between mangrove species or mangrove conditions (e.g., unhealthy stands). Conversely, Synthetic Aperture Radar (SAR) satellites actively emit microwave energy to their targets. The returning radar signals from the surface (i.e. backscatter) are very sensitive to dielectric and geometric properties of mangrove canopies and can thus also be used as an alternative or supplement to optical mapping procedures.

To date the vast majority of investigations using space-borne platforms to map and monitor mangroves have focused on optical sensors, primarily from the traditional/conventional SPOT and Landsat satellite series. These satellites have been used to map mangroves in a myriad of countries including, for example, Australia (Long and Skewes, 1996), Brazil (Brondizio et al., 1996), New Zealand (Gao, 1998), Thailand (Webb et al., 2000), the Turks and Caicos Islands (Green et al., 1998), the United Arab Emirates (Saito et al., 2003) and Vietnam (Tong et al., 2004). In comparison to the recent launch of very high resolution optical satellites (e.g., IKONOS in 1999), these traditional sensors are limited in spatial resolution (e.g., $\sim 1 \mathrm{~m}$ versus $\sim 25 \mathrm{~m}$ pixel size). However, these satellite data are cheaper, provide a larger coverage per acquisition, are easier to process and have extensive records (e.g., Landsat data extending back to 1972).

Consequently, they continue to play a very crucial role in assessing historical changes in mangrove forests. For example, multi-temporal SPOT and multi-temporal Landsat images have been used to determine the rates of mangrove forest degradation occurring in Madagascar (Rasolofoharinoro et al., 1998) and Mexico (Kovacs et al., 2001a), respectively, both resulting from hydrologic modification incurred from channel projects. Rates of mangrove gradation and degradation resulting from natural cycles of coastal accretion and erosion have also been determined for the coast of French Guiana using multi-date SPOT satellite data (Fromard et al., 2004) and for the Para coastline (North Brazil) using multi-date Landsat data (Cohen and Lara, 2003). Multitemporal satellite data have even been used to quantify the success of mangrove forest recovery resulting from the implementation government regulations on mangrove protection in Thailand (Muttitanon and Tripathi, 2005) and from very recent mangrove reforestation projects initiated by the Red Cross in Vietnam (Beland et al., 2006).

One major limitation to the use of the conventional sensors has been the inability to distinguish mangroves at the species level. In the aforementioned studies, mangroves are either simply separated from non-mangrove land cover/land use areas or they are further subdivided into 2-7 broad qualitative mangrove classes such as dense/tall or short/sparse mangroves. In a few circumstances, tall dense Rhizophora species have been mapped using Landsat data. Such mapping scales may suffice for many mangrove policy and management programs, especially in countries where only one species exists (e.g. New Zealand), but they could seriously hinder efforts where socio-economic policies on mangroves are based at the species level. Fortunately, studies in Panama (Wang et al., 2004a, b), Mexico (Kovacs et al., 2005) and Sri Lanka
(Dahdouh-Guebas et al., 2005a) have shown that with the very high resolution optical satellites (IKONOS and Quickbird) mangroves can be accurately mapped at the species level from space.

Whilst the number of studies is extremely limited, researchers have shown that space-borne SAR can be used in conjunction with optical data or as an alternative in the mapping of mangroves (Aschbacher et al., 1995; Dwivedi et al., 1999; Kushwaha et al., 2000; Simard et al., 2002). The main advantages of SAR are that it is not limited to daylight and, most importantly, it can penetrate cloud cover. Consequently, in cloud persistent areas of the tropics, it may be the only viable method for mangrove monitoring. Moreover, depending on the polarization, incidence angle and wavelength, SAR can penetrate forest canopies providing additional information that is not possible from optical sensors. The studies of space-borne SAR have, to date, been limited to older SAR satellites which are limited not only in spatial resolution but in flexibility of incidence angle and polarization mode acquisition options. With the recent launch of a new generation of SAR satellites (e.g., C-band Radarsat-2, L-band ALOS Palsar), it is anticipated that, with their technological advancements (e.g., fully polarimetric capabilities), SAR mangrove mapping accuracies will dramatically improve.

Thus far, all of the studies cited have indicated that mangrove aerial extent can be mapped accurately from space and that these sensors can provide an effective method for long-term mangrove monitoring. However, in some circumstances, resource managers and policy-makers may require quantitative data (i.e., biophysical parameters) of their mangrove forests including measures of tree height, basal area, stem density and even biomass indicators such as Leaf Area Index (LAI) and allometric equations (cf. Komiyama et al., 2008). For example, they may wish to model the ecological response of a mangrove forest to hurricanes (Kovacs et al., 2001b) or determine how the biophysical parameters of their mangrove are modified by local cuttings (Walters, 2005b). Quantitative studies using remote sensing techniques require, initially, a significant amount of field data collection and are thus laborintensive and expensive to conduct and possibly why so few of these studies are available.

With regards to conventional optical satellite data, significant relationships have been found between SPOT vegetation indices and both mangrove percent canopy closure (Jensen et al., 1991) and mangrove LAI (Green et al., 1997). Using simulated data, results from one study (Ramsey and Jensen, 1996) have also indicated that vegetation indices derived from Landsat and AVHRR data can also be correlated with mangrove LAI. More recently, significant relationships between mangrove LAI and IKONOS data have also been established (Kovacs et al., 2004a, b). Consequently, this parameter can now be estimated from optical satellite data at even the species level (Kovacs et al., 2005). As previously indicated, SAR can not only provide information on the geometry and water content of forest canopies but, in some circumstances, even collect data from below the canopy layer. For example, although using airborne and not space-borne SAR, researchers (Mougin et al., 1999) in French Guiana have found not only significant relationships with radar backscatter and both mangrove height and biomass but also with mangrove stem density and basal area. With regards to spaceborne SAR platforms, significant relationships have also been found between radar backscatter and mangrove LAI using both Radarsat-1 (Kovacs et al., 2006) and ENVISAT ASAR (Kovacs et al., 2008) satellite data. It is again anticipated that with the new generation of SAR satellites other mangrove forest biophysical parameter data could be extracted using radar backscatter signals.

Given the aforementioned advances in Earth observational imaging, it is no surprise that the availability of these data have significantly improved the ability of policy-makers and resource 
managers to monitor socio-economic impacts on their mangrove forests. Moreover, and possibly just as important, is the availability of these data to the general public. Specifically, satellite imagery, although in a limited format (e.g., limited spectral resolution), are now available on internet free access virtual globe programs such as Google Earth. In the hands of the public, these new tools could significantly alter the socio-economic dynamics associated with these forests at even the most local of scales.

\section{Conclusions and future directions}

Research on the human dimensions of mangrove forests remains a relatively new frontier. While not intended to provide a comprehensive list of possible research topics, these concluding comments suggest several key priorities.

There are a growing number of studies which examine local resource utilization and valuation of mangroves, yet coverage is patchy: limited to a relatively small number of sites, concentrated within a few biogeographic regions (esp. East Africa, Southeast Asia and the Indian subcontinent), and typically conducted over short time frames. Significant mangrove regions remain understudied (e.g., West Africa, South America, Indonesia). Furthermore, most of these studies exist in relative isolation from one another, yet opportunities to extract regional and global patterns are now warranted. Research that incorporates multi-year time frames and historical perspectives are particularly relevant given the rapid socio-economic and environmental changes unfolding along most tropical coastlines today. Likewise, there is need for economic valuation studies that explicitly focus on mangrove resources that are not marketed, but rather harvested and consumed directly by coastal households.

Studies that pay careful attention to the actual ecology of resource use are especially critical in light of the widespread influence of people on mangrove ecosystems (Walters, 2005b). Understanding how and why people actually harvest forest and aquatic resources in space and over time within a mangrove, and how these patterns of use impact the condition of the forest, is also vital for effective management, yet such information is almost always absent in planning and policy discussions. Standardised collection of this type of information from the local inhabitants is a first step in assuring that policy and law are anchored in local environmental and socio-economic reality (e.g., Kaplowitz, 2001; Omodei-Zorini et al., 2004; Walters, 2004; Dahdouh-Guebas et al., 2006a; Rist and Dahdouh-Guebas, 2006).

Location-specific studies should likewise be integrated with research that explicitly seeks to understand the range of human forces that impact mangroves less directly, but often more widely. Among these influences include (i) hydrological diversions caused by infrastructure developments along the coast or upstream of deltaic mangroves (e.g., dams); (ii) public policies with bearing on coastal natural resources, land use and development; (iii) markets for trade in mangrove products and products cultivated on former mangrove lands; and (iv) changes in sea level, rainfall and storm events associated with climate change.

The problems facing mangroves are dual: growing coastal populations put greater pressure on the ecosystem from the landward side, while global climate change, particularly sea-level rise, will increasingly put pressure on the mangrove from the seaward side. While the forest is squeezed as an ecosystem between these pressures, coastal subsistence users will be increasingly squeezed by economic pressures and public policies that respond to the same issues of overpopulation and global change. If resource management and land-use planning options to cope with these likely conditions are not effectively anticipated, both mangroves and the people who depend on them stand to lose.

\section{Acknowledgements}

Brad Walters' current research is funded by the Social Sciences and Humanities Research Council of Canada. Patrik Rönnbäck's and Farid Dahdouh-Guebas' research was funded by the EU (INCO-DC contract no. 510863). John Kovacs' research is funded by the Natural Sciences and Engineering Research Council of Canada (249496-06). Jurgenne Primavera's mangrove rehabilitation projects are funded by a grant from the Pew Fellowship program in Marine Conservation.

\section{References}

Adegbehin, J.O., 1993. Mangroves in Nigeria. In: Diop, E.S. (Ed.), Conservation and Sustainable Utilization of Mangrove Forests in Latin America and African Regions (Part 2: Africa). Mangrove Ecosystem Technical Reports 3, International Society for Mangrove Ecosystems and International Tropical Timber Organization, Tokyo, pp. 135-153.

Aksornkoae, S., Piebprom, S., Saraya, A., Kongsangchai, J., 1986. Mangrove resources and the socio-economics of dwellers in mangrove forests in Thailand. In: Kunstadter, P., Bird, E.C.F., Sabhasri, S. (Eds.), Man in the Mangroves. United Nations University, Tokyo, pp. 11-43.

Allen, J.A., Ewel, K.C., Keeland, B.D., Tara, T., Smith III, T.J., 2000. Downed wood in Micronesian mangrove forests. Wetlands 20, 169-176.

Allen, J.A., Ewel, K.C., Jack, J., 2001. Patterns of natural and anthropogenic disturbance of the mangroves on the Pacific island of Kosrae. Wetland Ecol. Manage. 9 279-289.

Alongi, D.M., 2002. Present state and future of the world's mangrove forests. Environ. Conserv. 29, 331-349.

Alongi, D.M., Tirendi, F., Trott, L.A., Xuan, T.T., 2000. Benthic decomposition rates and pathways in plantations of the mangrove Rhizophora apiculata in the Mekong delta, Vietnam. Mar. Ecol. Progr. Ser. 194, 87-101.

Alvarez-Leon, R., 1993. Mangrove ecosystems of Columbia. In: Lacerda, L.D. (Ed.) Conservation and Sustainable Utilization of Mangrove Forests in Latin America and African regions (Part 1: Latin America). Mangrove Ecosystem Technical Reports 2, International Society for Mangrove Ecosystems and International Tropical Timber Organization, Tokyo, pp. 75-114.

Armitage, D., 2002. Socio-institutional dynamics and the political ecology of mangrove forest conservation in Central Sulawesi, Indonesia. Global Environ. Change 12, 203-217.

Aschbacher, J., Ofren, R., Delsol, J.P., Suselo, T.B., Vibulsresth, S., Charrupat, T., 1995. An integrated comparative approach to mangrove vegetation mapping using advanced remote sensing and GIS technologies: preliminary results. Hydrobiologia 295, 285-294.

Ayukai, T., 1998. Introduction: carbon fixation and storage in mangroves and their relevance to the global climate change-a case study in Hinchinbrook Channel in northeastern Australia. Mangr. Salt Marsh. 2, 189-190.

Azariah, J., Selvam, V., Gunasekaran, S., 1992. Impact of past management practices on the present status of the Muthupet mangrove ecosystem. Hydrobiologia 247, 253-259.

Badola, R., Hussain, S.A., 2005. Valuing ecosystems functions: an empirical study on the storm protection function of Bhitarkanika mangrove ecosystem, India. Environ. Conserv. 32, 85-92.

Bagarinao, T.U., 1994. Systematics, genetics, distribution and life history of milkfish Chanos chanos. Environ. Biol. Fish. 39, 23-41.

Bagarinao, T.U., Primavera, J.H., 2005. Code of Practice for Sustainable Use of Mangrove Ecosystems for Aquaculture in Southeast Asia. SEAFDEC Aquaculture Department, Iloilo, Philippines, $47 \mathrm{pp}$.

Bailey, C., 1988. The social consequences of tropical shrimp mariculture development. Ocean Shore Manage. 11, 31-44.

Baird, A.H. 2006. Myth of green belts. Samudra Report 44, 14-19.

Balmford, A., Bruner, A., Cooper, P., Costanza, R., Farber, S., Green, R.E., Jenkins, M., Jefferiss, P., Jessamy, V., Madden, J., Munro, K., Myers, N., Naeem, S., Paavola, J., Rayment, M., Rosendo, S., Roughgarden, J., Trumper, K., Turner, R.K., 2002. Economic reasons for conserving wild nature. Science 297. 950-953.

Bandaranayake, W.M., 1998. Traditional and medicinal uses of mangroves. Mangr. Salt Marsh. 2, 133-148.

Bandaranayake, W.M., 2002. Bioactivities, bioactive compounds and chemical constituents of mangrove plants. Wetland Ecol. Manage. 10, 421-452.

Baran, E., Hambrey, J., 1998. Mangrove conservation and coastal management in southeast Asia: what impact on fishery resources? Mar. Pollut. Bull. 37 (8-12), 431-440.

Barbier, E.B., 1994. Valuing environmental functions: tropical wetlands. Land Econ. 70, 155-173.

Barbier, E.B., 2003. Habitat-fishery linkages and mangrove loss in Thailand. Contemp. Econ. Policy 21, 59-77.

Barbier, E.B., 2006. Natural barriers to natural disasters: replanting mangroves after the tsunami. Front. Ecol. Environ. 4, 124-131.

Barbier, E.B., 2007. Valuing ecosystem services as productive inputs. Econ. Policy 22, 177-229. 
Barbier, E.B., Strand, I., 1998. Valuing mangrove-fishery linkages: a case study of Campeche, Mexico. Environ. Res. Econ. 12, 151-166.

Barbier, E.B., Cox, M., 2003. Does economic development lead to mangrove loss? A cross-country analysis. Contemp. Econ. Policy 21, 418-432.

Barletta-Bergan, A., Barletta, M., Saint-Paul, U., 2002a. Community structure and temporal variability of ichthyoplankton in North Brazilian mangrove creeks. J. Fish Biol. 61, 33-51.

Barletta-Bergan, A., Barletta, M., Saint-Paul, U., 2002b. Structure and seasonal dynamics of larval fish in the Caeté River Estuary in North Brazil. Estuar. Coast. Shelf Sci. 54, 193-206.

Barnes, D.K.A., 2001. Hermit crabs, humans and Mozambique mangroves. Afr. J. Ecol. 39, 241-248.

Bart, D., 2006. Integrating local ecological knowledge and manipulative experiments to find the causes of environmental change. Front. Ecol. Environ. 4, 541546.

Bashirullah, A.K.M., Mahmood, N., Matin, A.K.M.A., 1989. Aquaculture and coastal zone management in Bangladesh. Coast. Zone Manage. 17, 119-127.

Basit, M.A., 1995. Non-wood forest products from the mangrove forests of Bangladesh. In: Beyond timber: Social, economic and cultural dimensions of non wood forest products. Report 1995/13, Food and Agriculture Organization of the United Nations, Rome.

Beland, M., Goita, K., Bonn, F., Pham, T.T.H., 2006. Assessment of land-cover changes related to shrimp aquaculture using remote sensing data: a case study in the Giao Thuy District, Vietnam. Int. J. Remote Sens. 27, 1491-1510.

Bennett, E.L., Reynolds, C.J., 1993. The value of a mangrove area in Sarawak. Biodiv. Conserv. 2, 359-375.

Berger, U., Rivera-Monroy, V.H., Doyle, T.W., Dahdouh-Guebas, F., Duke, N.C., Fontalvo-Herazo, M.L., Hildenbrandt, H., Koedam, N., Mehlig, U., Piou, C., Twilley, R.R., 2008. Advances and limitations of individual-based models to analyze and predict dynamics of mangrove forests: A review. Aquat. Bot. 89, 260-274.

Berkes, F., 1999. Sacred Ecology: Traditional Ecological Knowledge and Resource Management. Taylor \& Francis, Philadelphia.

Berlin, B., 1973. Folk systematics in relation to biological classification and nomenclature. Ann. Rev. Ecol. Syst. 4, 259-271.

Bhatta, R., Bhat, M., 1998. Impacts of aquaculture on the management of estuaries in India. Environ. Conserv. 25, 109-121.

Bhattacharyya, J., 1990. Uses, values, and use values of the Sundarbans. Agric. Hum. Val. 7, 34-39.

Blanchard, J., Prado, G., 1995. Natural regeneration of Rhizophora mangle in strip clearcuts in Northwest Ecuador. Biotrop. 27, 160-167.

Bosire, J.O., Dahdouh-Guebas, F., Kairo, J.G., Koedam, N., 2003. Colonization of nonplanted mangrove species into restored mangrove stands in Gazi Bay, Kenya. Aquat. Bot. 76, 267-279.

Bosire, J.O., Dahdouh-Guebas, F., Kairo, J.G., Cannicci, S., Koedam, N., 2004. Spatial variations in macrobenthic fauna recolonisation in a tropical mangrove bay. Biodiv. Conserv. 13 (6), 1059-1074.

Bosire, J.O., Dahdouh-Guebas, F., Kairo, J.G., Kazungu, J., Dehairs, F., Koedam, N., 2005a. Litter degradation and CN dynamics in reforested mangrove plantations at Gazi Bay, Kenya. Biol. Conserv. 126, 287-296.

Bosire, J.O., Kazungu, J., Koedam, N., Dahdouh-Guebas, F., 2005b. Predation on propagules regulates regeneration in a high-density reforested mangrove plantation. Mar. Ecol. Progr. Ser. 299, 149-155.

Bosire, J.O., Dahdouh-Guebas, F., Kairo, J.G., Wartel, S., Kazungu, J., Koedam, N., 2006. Success rates and recruited tree species and their contribution to the structural development of reforested mangrove stands. Mar. Ecol. Progr. Ser. 325, 85-91.

Bosire, J.O., Dahdouh-Guebas, F., Walton, M., Crona, B.I., Lewis III, R.R., Field, C., Kairo, J.G., Koedam, N., 2008. Functionality of restored mangroves: A review. Aquat. Bot. 89, 251-259.

Brondizio, E., Moran, E., Mausel, P., Wu, Y., 1996. Land cover in the Amazon estuary: linking of the thematic mapper with botanical and historical data. Photogramm. Eng. Remote Sens. 62, 921-929.

Brown, W.H., Fischer, A.F., 1918. Philippine mangrove swamps. Bulletin No. 17, Bureau of Forestry, Department of Agriculture and Natural Resources, Manila.

Cabahug, Jr., D.M., Ambi, F.M., Nisperos, S.O., Truzan, Jr., N.C., 1986. Impact of community-based mangrove forestation to mangrove dependent families and to nearby coastal areas in Central Visayas: a case example. In: National Mangrove Committee (Ed.), Mangroves of Asia and the Pacific: Status and Management. Natural Resources Management Center, Ministry of Natural Resources, Quezon City, Philippines, pp. 441-466.

Cabrera, M.A., Seijo, J.C., Euan, J., Perez, E., 1998. Economic values of ecological services from a mangrove ecosystem. Intercoast Net. 32, 1-2.

Cannicci, S., Burrows, D., Fratini, S., Smith III, T.J., Offenberg, J., Dahdouh-Guebas, F., 2008. Faunistic impact on vegetation structure and ecosystem function in mangrove forests: A review. Aquat. Bot. 89, 186-200.

Carlton, J.M., Moffler, M.D., 1978. Propagation on mangroves by air-layering. Environ. Conserv. 5, 147-150.

Chan, H.T., 1996. Mangrove reforestation in peninsular Malaysia: a case study of Matang. In: Field, C.D. (Ed.), Restoration of Mangrove Ecosystems. International Society for Mangrove Ecosystems, Okinawa, Japan.

Chang, L., Peng, L., 1987. Economic value of mangrove communities in China. In: Field, C.D., Dartnall, A.J. (Eds.), Mangrove Ecosystems of Asia and the Pacific: Status, Exploitation and Management. Australian Development Assistance Bureau and Australian Committee for Mangrove Research, Townsville, pp. 143-149.
Chapman, V.J., 1976. Mangrove Vegetation. Strauss \& Cramer, Leutershausen, Germany.

Chong, V.C., 2007. Mangrove-fisheries linkages-the Malaysian perspective. Bull. Mar. Sci. 80, 755-772.

Chong, V.C., Sasekumar, A., Leh, M.U.C., D'Cruz, R., 1990. The fish and prawn communities of a Malaysian coastal mangrove system, with comparisons to adjacent mud flats and inshore waters. Estuar. Coast. Shelf Sci. 31, 703-722.

Chong, V.C., Sasekumar, A., Wolanski, E., 1996. The role of mangroves in retaining penaeid prawn larvae in Klang Strait, Malaysia. Mang. Salt Marsh. 1, 11-22.

Christensen, B., 1982. Management and utilization of mangroves in Asia and the Pacific. FAO Environment Paper No. 3, Food and Agriculture Organization, Rome.

Christensen, B., 1983a. Report on Malaysia's mangrove management. Unasylva 35 10-15.

Christensen, B., 1983b. Mangroves: what are they worth? Unasylva 35, 2-10.

Clough, B.F., Ong, J.E., Gong, W.K., 1997. Estimating leaf area index and photosynthetic production in canopies of the mangrove Rhizophora apiculata. Mar. Ecol. Progr. Ser. 159, 285-292.

Cohen, M.C.L., Lara, R.J., 2003. Temporal changes of mangroves vegetation boundaries in Amazonia: application of GIS and remote sensing techniques. Wetl. Ecol. Manage. 11, 223-231.

Cormier-Salem, M., 1999. The mangrove: an area to be cleared... for social scientists. Hydrobiologia 413, 135-142.

Costanza, R., Faber, C., Maxwell, J., 1989. The valuation and management of wetland ecosystems. Ecol. Econ. 1, 335-361.

Crona, B.I., 2006. Supporting and enhancing development of heterogeneous ecological knowledge among resource users in a Kenyan seascape. Ecol. Soc. 11 (1) art 32.

Crona, B.I., Rönnbäck, P., 2005. Use of replanted mangroves as nursery grounds by shrimp communities in Gazi Bay, Kenya. Estuar. Coast. Shelf Sci. 65, 535-544.

Crona, B.I., Rönnbäck, P., 2007. Community structure and temporal variability of juvenile fish assemblages in natural and replanted mangroves, Sonneratia alba Sm., of Gazi Bay, Kenya. Estuar. Coast. Shelf Sci. 74, 44-52.

Crona, B.I., Holmgren, S., Rönnbäck, P., 2006. Re-establishment of epi-biotic communities in reforested mangroves of Gazi Bay, Kenya. Wetland Ecol. Manage. 14 $527-538$.

Curtis, S.J., 1933. Working Plans for the Forests of the Sundarbans Division for the Period From 1st April 1931 to 31st March 1951, vol. 1. Bengal Government Press, Calcutta, India.

Dahdouh-Guebas, F., 2006. Mangrove forests and tsunami protection. McGraw-Hill Yearbook of Science \& Technology. McGraw-Hill Professional, New York, pp. 187-191.

Dahdouh-Guebas, F., Koedam, N., 2006. Coastal vegetation and the Asian tsunami. Science 311, 37-38.

Dahdouh-Guebas, F., Verheyden, A., De Genst, W., Hettiarachchi, S., Koedam, N., 2000a. Four decade vegetation dynamics in Sri Lankan mangroves as detected from sequential aerial photography: a case study in Galle. Bull. Mar. Sci. 67, $741-759$.

Dahdouh-Guebas, F., Mathenge, C., Kairo, J.G., Koedam, N., 2000b. Utilization of mangrove wood products around Mida Creek (Kenya) amongst subsistence and commercial users. Econ. Bot. 54, 513-527.

Dahdouh-Guebas, F., Zetterstrom, T., Rönnbäck, P., Troell, M., Wickramasinghe, A., Koedam, N., 2002. Recent changes in land use in the Pambala-Chilaw lagoon complex (Sri Lanka) investigated using remote sensing and GIS: conservation of mangroves vs. development of shrimp farming. Environ. Develop. Sustain. 4, $185-200$.

Dahdouh-Guebas, F., Van Pottelbergh, I., Kairo, J.G., Cannicci, S., Koedam, N., 2004 Human-impacted mangroves in Gazi (Kenya): predicting future vegetation based on retrospective remote sensing, social surveys, and distribution of trees. Mar. Ecol. Progr. Ser. 272, 77-92.

Dahdouh-Guebas, F., Van Hiel, E., Chan, J.C.-W., Jayatissa, L.P., Koedam, N., 2005a. Qualitative distinction of congeneric and introgressive mangrove species in mixed patchy forest assemblages using high spatial resolution remotely sensed imagery (IKONOS). Syst. Biodiv. 2, 113-119.

Dahdouh-Guebas, F., Hettiarachchi, S., Lo Seen, D., Batelaan, O., Sooriyarachchi, S. Jayatissa, L.P., Koedam, N., 2005b. Transitions in ancient inland freshwate resource management in Sri Lanka affect biota and human populations in and around coastal lagoons. Curr. Biol. 15, 579-586.

Dahdouh-Guebas, F., Jayatissa, L.P., Di Nitto, D., Bosire, J.O., Lo Seen, D., Koedam, N. 2005c. How effective were mangroves as a defense against the recent tsunami? Curr. Biol. 15, R443-R447.

Dahdouh-Guebas, F., Collin, S., Lo Seen, D., Rönnbäck, P., Depommier, D., Ravishankar, T., Koedam, N., 2006a. Analysing ethnobotanical and fishery-related importance of mangroves of East-Godavari Delta (Andhra Pradesh, India) for conservation and management purposes. J. Ethnobiol. Ethnomed. 2, art24.

Dahdouh-Guebas, F., Verheyden, A., Kairo, J.G., Jayatissa, L.P., Koedam, N., 2006b. Capacity building in tropical coastal resource monitoring in developing countries: a re-appreciation of the oldest remote sensing method. Int. J. Sustain. Develop. World Ecol. 13, 62-76.

Dall, W., Hill, B.J., Rothlisberg, P.C., Staples, D.J., 1990. The biology of the Penaeidae Adv. Mar. Biol. 27, 1-489.

Danielsen, F., Sørensen, M.K., Olwig, M.F., Selvam, V., Parish, F., Burgess, N.D. Hiraishi, T., Karunagaran, V.M., Rasmussen, M.S., Hansen, L.B., Quarto, A Suryadiputra, N., 2005. The asian tsunami: a protective role for coastal vegetation. Science $310,643$. 
Davis, A., Wagner, J.R., 2003. Who knows? On the importance of identifying 'experts' when researching local ecological knowledge. Hum. Ecol. 31, 463-489.

de Graaf, G.J., Xuan, T.T., 1998. Extensive shrimp farming, mangrove clearance and marine fisheries in the southern provinces of Vietnam. Mangr. Salt. Marsh. 2, 159-166.

Dewalt, B.R., Vergne, P., Hardin, M., 1996. Shrimp aquaculture development and the environment: people, mangroves and fisheries on the Gulf of Fonseca, Honduras. World Develop. 24, 1193-1208.

Diop, E.S. (Ed.), 1993. Conservation and sustainable utilization of mangrove forests in Latin America and African regions (Part 2: Africa). Mangrove Ecosystem Technical Reports 3, International Society for Mangrove Ecosystems and International Tropical Timber Organization, Tokyo.

Duke, N.C., Meynecke, J.-O., Dittmann, S., Ellison, A.M., Anger, K., Berger, U., Cannicci, S., Diele, K., Ewel, K.C., Field, C.D., Koedam, N., Lee, S.Y., Marchand, C., Nordhaus, I., Dahdouh-Guebas, F., 2007. A world without mangroves? Science 317, 41-42.

Dwivedi, R.S., Rao, B.R.M., Bhattacharya, S., 1999. Mapping wetlands of the Sundarban Delta and it's environs using ERS-1 SAR data. Int. J. Remote Sens. 20, 2235-2247.

Ellison, A.M., 2000. Mangrove restoration: do we know enough. Restor. Ecol. 8 219-229.

Ellison, A.M., Farnsworth, E.J., 1996. Anthropogenic disturbance of Caribbean mangrove ecosystems: past impacts, present trends, and future predictions. Biotrop. $28,549-565$

Elster, C., 2000. Reasons for reforestation success and failure with three mangrove species in Columbia. For. Ecol. Manage. 131, 201-214.

Ewel, K.C., Twilley, R.R., Ong, J.E., 1998a. Different kinds of mangrove forests provide different goods and services. Global Ecol. Biogeogr. 7, 83-94.

Ewel, K.C., Zheng, S., Pinzon, Z., Bourgeois, J.A., 1998b. Environmental effects of canopy gap formation in high-rainfall mangrove forests. Biotrop. 30, 510-518.

FAO, 1985. Mangrove management in Thailand, Malaysia and Indonesia. FAO Environment Paper 4, Food and Agriculture Organization of the United Nations, Rome.

FAO, 1994. Mangrove forest management guidelines. FAO Forestry Paper 117, Food and Agriculture Organization of the United Nations, Rome.

Farber, S., 1987. The value of coastal wetlands for protection of property against hurricane wind damage. J. Environ. Econ. Manage. 14, 143-151.

Farnsworth, E.J., Ellison, A.M., 1997. The global conservation status of mangroves. Ambio 26, 328-334.

Festinger, L.A., 1957. Theory of Cognitive Dissonance. Row, Peterson, New York.

Field, C.D. (Ed.), 1996. Restoration of Mangrove Ecosystems. International Society of Mangrove Ecosystems and ITTO, Okinawa, Japan.

Field, C.D., 1998. Rehabilitation of mangrove ecosystems: an overview. Mar. Poll Bull. 37, 383-392.

Field, C.D., Dartnall, A.J. (Eds.), 1987. Mangrove Ecosystems of Asia and the Pacific: Status, Exploitation and Management. Australian Development Assistance Bureau and Australian Committee for Mangrove Research, Townsville.

Fong, F.W., 1992. Perspectives for sustainable resource utilization and management of nipa vegetation. Econ. Bot. 46, 45-54.

Fosberg F.R. 1971. Mangroves versus tidal waves. Biol Conserv, 4, 38-39.

Fromard, F., Vega, C., Proisy, C., 2004. Half a century of dynamic coastal change affecting mangrove shorelines of French Guiana: a case study based on remote sensing data analyses and field surveys. Mar. Geol. 208, 265-280.

Furukawa, K., Wolanski, E., Mueller, H., 1997. Currents and sediment transport in mangrove forests. Estuar. Coast. Shelf Sci. 44, 301-310.

Gao, J., 1998. A hybrid method toward accurate mapping of mangroves in a margina habitat from SPOT multispectral data. Int. J. Remote Sens. 19, 1887-1899.

Gattuso, J.P., Frankignoulle, M., Wollast, R., 1998. Carbon and carbonate metabolism in coastal aquatic ecosystems. A. Rev. Ecol. Syst. 29, 405-434.

Ghimire, S.K., McKey, D., Aumeeruddy-Thomas, Y., 2004. Heterogeneity in ethnoecological knowledge and management of medicinal plants in the Himalayas of Nepal: Implications for conservation. Ecol. Soc. 9 (3) art 6.

Gilman, E.L., Ellison, J., Duke, N.C., Field, C., 2008. Threats to mangroves from climate change and adaptation options: A review. Aquat. Bot. 89, 237-250.

Glaser, M., 2003. Interrelations between mangrove ecosystem, local economy and social sustainability in Caete Estuary, North Brazil. Wetland Ecol. Manage. 11, 265-272.

Glaser, M., Oliveira, R., 2004. Prospects for the co-management of mangrove ecosystems on the North Brazilian coast: whose rights, whose duties and whose priorities? Nat. Resour. Forum 28, 224-233.

Gong, W.K., Ong, J.E., 1995. The use of demographic studies in mangrove silviculture. Hydrobiologia 295, 255-261

Gong, W.K., Ong, J.E., Wong, C.H., Dhanarajan, G., 1980. Productivity of mangrove trees and its significance in a managed mangrove ecosystem in Malaysia. Mangrove Environmental Research and Management, University of Malaysia, Kuala Lumpur and UNESCO.

Green, E.P., Mumby, P.J., Alaisdair, E.J., Clark, C.D., Ellis, A.C., 1997. Estimating lea area index of mangroves from satellite data. Aquat. Bot. 58, 11-19.

Green, E.P., Clark, C.D., Mumby, P.J., Edwards, A.J., Ellis, A.C., 1998. Remote sensing techniques for mangrove mapping. Int. J. Remote Sens. 19, 935-956.

Hamilton, L.S., Snedaker, S.C. (Eds.), 1984. Handbook for Mangrove Area Management. IUCN/Unesco/UNEP. East-West Centre, Honolulu, Hawaii.

Hamilton, L.S., Dixon, J.A., Miller, G.O., 1989. Mangrove forests: an undervalued resource of the land and of the sea. In: Borgese, E.M., Ginsburg, N., Morgan, J.R. (Eds.), Ocean Yearbook 8. University of Chicago Press, Chicago, pp. 254288 .
Harakunarak, A., Aksornkoae, S., July 2005. Life-saving belts: post-tsunami reassessment of mangrove ecosystem values and management in Thailand. Trop. Coasts 2005, 48-55.

Hauff, R.D., Ewel, K.C., Jack, J., 2006. Tracking human disturbance in mangroves: estimating harvest rates on a Micronesian island. Wet. Ecol. Manage 14, 95105.

Hernández Cornejo, R., Koedam, N., Ruiz Luna, A., Troell, M., Dahdouh-Guebas, F. 2005. Remote sensing and ethnobotanical assessment of the mangrove forest changes in the Navachiste-San Ignacio-Macapule lagoon complex, Sinaloa, Mexico. Ecol. Soc. 10 (1) art 16.

Hong, P.N. (Ed.), 2006. The Role of Mangrove and Coral Reef Ecosystems in Natural Disaster Mitigation and Coastal Life Improvement. The World Conservation Union, and Mangrove Ecosystem Research Division, Viet Nam National University, Hanoi. 386 pp.

Hoq, M.E., 2007. An analysis of fisheries exploitation and management practices in the Sundarbans mangrove ecosystem, Bangladesh. Ocean Coast. Manage. 50, 411-427.

Hussain, M.Z., 1995. Silviculture of mangroves. Unasylva 181 (46), 36-42.

Hussain, M.Z., Ahmed, I., 1994. Management of forest resources. In: Hussain, M.Z. Acharya, G. (Eds.), Mangroves of the Sundarbans, vol. 2. IUCN, Bangladesh.

IUCN, 2005. Economic value of mangroves: a case study to value the shoreline protection, goods and services provided by healthy mangroves. IUCN Tsunami Response, 1-2.

Jayatissa, L.P., Hettiarachchi, S., Dahdouh-Guebas, F., 2006. An attempt to recover economic losses from decadal changes in two lagoon systems of Sri Lanka through a newly patented mangrove product. Environ. Dev. Sustain. 8, 585595.

Jensen, J.R., Lin, H., Yang, Y., Ramsey, E., Davis, B.A., Thoemke, C.W., 1991. The measurement of mangrove characteristics in Southwest Florida using SPOT multispectral data. Geocarto Int. 2, 13-21.

Kairo, J.G., Dahdouh-Guebas, F., Bosire, J., Koedam, N., 2001. Restoration and management of mangrove systems-a lesson for and from the East African region. S. Afr. J. Bot. 67, 383-389.

Kairo, J.G., Dahdouh-Guebas, F., Gwaba, P.O., Ochieng, C., Koedam, N., 2002. Regeneration status of mangrove forests in Mida Creek, Kenya: a compromised or secured future? Ambio 31, 562-568.

Kaly, U.L., Jones, G.P., 1998. Mangrove restoration: a potential tool for coastal management in tropical developing countries. Ambio 27, 656-661.

Kaplowitz, M.D., 2001. Assessing mangrove products and services at the local level: the use of focus groups and individual interviews. Landsc. Urban Plann. 56, $53-$ 60.

Kathiresan, K., 2003. How do mangrove forests induce sedimentation? Revista Biol. Trop. 51, 355-360.

Kathiresan, K., Bingham, B.L., 2001. Biology of mangroves and mangrove ecosystems. Adv. Mar. Biol. 40, 81-251.

Kathiresan, K., Rajendran, N., 2005. Coastal mangrove forests mitigated tsunami. Estuar. Coast. Shelf Sci. 65, 601-606.

Kautsky, N., Rönnbäck, P., Tedengren, M., Troell, M., 2000. Ecosystem perspectives on management of disease in shrimp pond farming. Aquaculture 191 (1-3), 145-161.

Kerr, A.M., Baird, A.H., 2007. Natural barriers to natural disasters. BioSci. 57, 102-103.

Komiyama, A., Ong, J.E., Poungparn, S., 2008. Allometry, biomass, and productivity of mangrove forests: A review. Aquat. Bot. 89, 128-137.

Kovacs, J.M., 1999. Assessing mangrove use at the local scale. Landsc. Urban Plann. 43, 201-208.

Kovacs, J.M., 2000. Perceptions of environmental change in a tropical coastal wetland. Land Degradr. Dev. 11, 209-220.

Kovacs, J.M., Wang, J., Blanco-Correa, M., 2001a. Mapping mangrove disturbances using multi-date Landsat TM imagery. Environ. Manage. 27, 763-776.

Kovacs, J.M., Blanco-Correa, M., Flores-Verdugo, F., 2001b. A logistic regression model of hurricane impacts in a mangrove forest of the Mexican Pacific. J. Coast. Res. 17, 30-37.

Kovacs, J.M., Flores-Verdugo, F., Wang, J., Aspden, L.P., 2004a. Estimating leaf area index of a degraded mangrove forest using high spatial resolution satellite data. Aquat. Bot. 80, 13-22.

Kovacs, J.M., Malczewski, J., Flores-Verdugo, F., 2004b. Examining local ecological knowledge of hurricane impacts in a mangrove forest using an Analytical Hierarchy Process (AHP) approach. J. Coast. Res. 20, 792-800.

Kovacs, J.M., Wang, J., Flores-Verdugo, F., 2005. Mapping mangrove leaf area index at the species level using IKONOS and LAI-2000 sensors. Estuar. Coast Shelf Sci. $62,377-384$.

Kovacs, J.M., Vandenberg, C.V., Flores-Verdugo, F., 2006. Assessing fine beam RADARSAT-1 backscatter from a white mangrove (Laguncularia racemosa (Gaertner)) canopy. Wetland Ecol. Manage. 14, 401-408.

Kovacs, J.M., Vandenberg, C.V., Wang, J., Flores-Verdugo, F., 2008. The use of multipolarized spaceborne SAR backscatter for monitoring the health of a degraded mangrove forest. J. Coast. Res. 24, 248-254.

Krause, G., Bock, M., Weiers, St., Braun, G., 2004. Mapping land-cover and mangrove structures with remote sensing techniques-a contribution to a synoptic GIS in support of coastal management in north Brazil. Environ. Manage. 34, 429440

Kristensen, E., Bouillon, S., Dittmar, T., Marchand, C., 2008. Organic carbon dynamics in mangrove ecosystems: A review. Aquat. Bot. 89, 201-219.

Kühlmann, D.H.H., 1988. The sensitivity of coral reefs to environmental pollution. Ambio 17, 13-21. 
Kunstadter, P., Bird, E.C.F., Sabhasri, S. (Eds.), 1986. Man in the Mangroves. United Nations University, Tokyo.

Kushwaha, S.P.S., Dwivedi, R.S., Rao, B.R.M., 2000. Evaluation of various digital image processing techniques for detection of coastal wetlands using ERS-1 SAR data. Int. J. Remote Sens. 21, 565-579.

Lacerda, L.D. (Ed.), 1993. Conservation and sustainable utilization of mangrove forests in Latin America and African regions (Part 1: Latin America). Mangrove Ecosystem Technical Reports 2, International Society for Mangrove Ecosystems and International Tropical Timber Organization, Tokyo.

Lacerda, L.D. (Ed.), 2002. Mangrove Ecosystems: Function and Management. Springer, New York.

Lacerda, L.D., Conde, J.E., Bacon, P.R., Alarcon, C., D'Croz, L., Kjerfve, B., Polania, J., Vanucci, M., 1993. Mangrove ecosystems in Latin America and the Caribbean: a summary. In: Lacerda, L.D. (Ed.), Conservation and Sustainable Utilization of Mangrove Forests in Latin America and African regions (Part 1: Latin America). Mangrove Ecosystem Technical Reports 2, International Society for Mangrove Ecosystems and International Tropical Timber Organization, Tokyo.

Lacerda, L.D., Conde, J.E., Kjerfve, B., Alvarez-Leon, R., Alarcon, C., Plania, J., 2002. American mangroves. In: Lacerda, L.D. (Ed.), Mangrove Ecosystems: Function and Management. Springer, New York, pp. 1-61.

Lal, P.N., 1990. Conservation or conversion of mangroves in Fiji: An ecological economic analysis.Occasional Paper No. 11, East-West Environment and Policy Institute, Honolulu, 108 pp.

Lal, P.N., 2002. Integrated and adaptive mangrove management framework-an action oriented option for the new millennium. In: Lacerda, L.D. (Ed.), Mangrove Ecosystems: Function and Management. Springer-Verlag, Berlin, pp. 235-256.

Lee, S.Y., 2004. Relationship between mangrove abundance and tropical prawn production: a re-evaluation. Mar. Biol. 145, 943-949.

Lewis, R.R., 1992. Coastal habitat restoration as a fishery management tool. In: Stroud, R.H. (Ed.), Stemming the Tide of Coastal Fish Habitat Loss. National Coalition for Marine Conservation, Inc, Savannah, pp. 169-173.

Lewis, R.R., 2000. Ecological based goal setting in mangrove forest and tidal marsh restoration. Ecol. Eng. 15, 191-198.

Lewis, R.R., 2005. Ecological engineering for successful management and restoration of mangrove forests. Ecol. Eng. 24, 403-418.

Liu, P.L.-F., Lynett, P., Fernando, H., Jaffe, B.E., Fritz, H., Higman, B., Morton, R., Goff, J., Synolakis, C., 2005. Observations by the international tsunami survey team in Sri Lanka. Science 308, 1595.

Long, B.G., Skewes, T.D., 1996. A technique for mapping mangroves with Landsat TM satellite data and geographic information system. Estuar. Coast. Shelf Sci. 43 , 373-381.

Lopez-Hoffman, L., Monroe, I.E., Narvaez, E., Martinez-Ramos, M., Ackerly, D.D., 2006. Sustainability of mangrove harvesting: how do harvesters' perceptions differ from ecological analysis? Ecol. Soc. 11 (2) art 14.

Macintosh, D.J., 1982. Fisheries and aquaculture significance of mangrove swamps, with special reference to the Indo-West Pacific region. In: Muir, J.F., Roberts, R.J. (Eds.), Recent Advances in Aquaculture. Croom Helm, England, pp. 4-85.

Macnae, W., 1968. A general account of the fauna and flora of mangrove swamps and forests in the Indo-West-Pacific region. Adv. Mar. Biol. 6, 73-270.

Magalhaes, A., da Costa, R.M., da Silva, R., Cajueiro, L., Pereira, C., 2007. The role of women in the mangrove crab (Ucides cordatus, Ocypodidae) production process in North Brazil (Amazon region, Pará). Ecol. Econ. 61, 559-565.

Mainoya, J.R., Mesaki, S., Banyikwa, F.F., 1986. The distribution and socio-economic aspects of mangrove forests in Tanzania. In: Kunstadter, P., Bird, E.C.F., Sabhasri, S. (Eds.), Man in the Mangroves. United Nations University, Tokyo, pp. 87-95.

Massel, S.R., Furukawa, K., Brinkman, R.M., 1999. Surface wave propagation in mangrove forests. Fluid Dyn. Res. 24, 219-249.

Mastaller, M., 1997. Mangroves, the Forgotten Forest between Land and Sea. Tropical Press Sdn. Bhd, Kuala Lumpur, Malaysia, 200.

Matthes, H., Kapetsky, J.M., 1988. Worldwide compendium of mangrove-associated aquatic species of economic importance. FAO Fishery Circular No. 814, FAO, Rome.

Mazda, Y., Magi, M., Kogo, M., Hong, P.N., 1997. Mangroves as a coastal protection from waves in the Tong King Delta, Vietnam. Mangr. Salt Marsh. 1, 127-135.

Meltzoff, S.K., LiPuma, E., 1986. The social and political economy of coastal zone management: Shrimp mariculture in Ecuador. Coast. Zone Manage. J. 14, 349380.

Millennium Ecosystem Assessment, 2005. Ecosystems and Human Well Being: Synthesis. World Resources Institute, Washington, DC.

Moberg, F., Rönnbäck, P., 2003. Ecosystem services of the tropical seascape: Interactions, substitutions, and restoration. Ocean Coast. Manage. 46, 27-46.

Moller, H., Berkes, F., 2004. Combining science and traditional ecological knowledge: monitoring populations for co-management. Ecol. Soc. 9 (3) art 2.

Morton, J.F., 1965. Can the red mangrove provide food, feed and fertilizer? Econ. Bot. 19, 113-123.

Mougin, E., Proisy, C., Marty, G., Fromard, F., Puig, H., Betoulle, J.L., Rudant, J.P., 1999. Multifrequency and multipolarization radar backscattering from mangrove forests. IEEE Trans. Geosci. Remote Sens. 37, 94-102.

Muttitanon, W., Tripathi, N.K., 2005. Land use/land cover changes in the coastal zone of Ban Don Bay, Thailand using Landsat TM data. Int. J. Remote Sens. 26, 231-2323.

Nagelkerken, I., van der Velde, G., 2004. Relative importance of interlinked mangroves and seagrass beds as feeding habitats for juvenile reef fish on a Caribbean island. Mar. Ecol. Progr. Ser. 274, 153-159.
Nagelkerken, I., Roberts, C.M., van der Velde, G., Dorenbosch, M., van Riel, M.C. Cocheret de la Moriniere, E., Nienhuis, P.H., 2002. How important are mangroves and seagrass beds for coral-reef fish? The nursery hypothesis tested on an island scale. Mar. Ecol. Progr. Ser. 244, 299-305.

Nagelkerken, I., Dorenbosch, M., Verberk, W.C.E.P., Cocheret de la Moriniere, E., van der Velde, G., 2000. Importance of shallow-water biotopes of a Caribbean bay for juvenile coral reef fishes: patterns in biotope association, community structure and spatial distribution. Mar. Ecol. Progr. Ser. 202, 175-192.

Nagelkerken, I., Blaber, S.J.M., Bouillon, S., Green, P., Haywood, M., Kirton, L.G. Meynecke, J.-O., Pawlik, J., Penrose, H.M., Sasekumar, A., Somerfield, P.J., 2008. The habitat function of mangroves for terrestrial and marine fauna: A review. Aquat. Bot. 89, 155-185.

Naylor, R.L., Drew, M., 1998. Valuing mangrove resources in Kosrae, Micronesia. Environ. Dev. Econ. 3, 471-490.

Naylor, R.L., Goldburg, R.J., Primavera, J.H., Kautsky, N., Beveridge, M., Clay, J., Folke, C., Lubchenco, J., Mooney, H., Troell, M., 2000. Effect of aquaculture on world fish supplies. Nature 405, 1017-1024.

Naylor, R.L., Bonine, K.B., Ewel, K.C., Waguk, E., 2002. Migration, markets and mangrove resource use on Kosrae, Federated States of Micronesia. Ambio 31, 340-350.

Nickerson, D.J., 1999. Trade-offs of mangrove area development in the Philippines. Ecol. Econ. 28, 279-298.

Nurkin, B., 1994. Degradation of mangrove forests in South Sulawesi, Indonesia. Hydrobiologia 285, 271-276.

Ogden, J.C., 1997. Ecosystem interactions in the tropical coastal seascape. In: Birkeland, C. (Ed.), Life and Death of Coral Reefs. Chapman \& Hall, London, pp. 288-297.

Omodei-Zorini, L., Contini, C., Jiddawi, N., Ochiewo, J., Shunula, J., Cannicci, S., 2004. Participatory appraisal for potential community-based mangrove management in East Africa. Wetland Ecol. Manage. 12, 87-102.

Ong, J.E., 1993. Mangroves-a carbon source and sink. Chemosph. 27, 1097-1107.

Ong, J.E., 1995. The ecology of mangrove conservation and management. Hydrobiologia 295, 343-351.

Othman, M.A., 1994. Value of mangroves in coastal protection. Hydrobiologia 285 277-282.

Overdorf, J., Unmacht, E., 2005. Why save the forests? Fear of big waves is no reason to plant mangroves. Newsweek CXLV (7) 49 (Feb. 14).

Pauly, D., Ingles, J., 1986. The relationship between shrimp yields and intertidal (mangrove) areas: a reassessment. In: IOC/FAO Workshop on Recruitment in Tropical Coastal Demersal Communities. IOC, UNESCO, Paris, pp. 227-284.

Pinzon, Z.S., Ewel, K.C., Putz, F.E., 2003. Gap formation and forest regeneration in Micronesian mangrove forest. J. Trop. Ecol. 19, 143-153.

Primavera, J.H., 1993. A critical review of shrimp pond culture in the Philippines. Rev. Fish. Sci. 1, 151-201.

Primavera, J.H., 1995. Mangroves and brackish water pond culture in the Philippines. Hydrobiologia 295, 303-309.

Primavera, J.H., 1998a. Tropical shrimp farming and its sustainability. In: de Silva, S. (Ed.), Tropical Mariculture. Academic Press, London, pp. 257-289.

Primavera, J.H., 1998b. Mangroves as nurseries: shrimp populations in mangrove and non-mangrove habitats. Estuar. Coast. Shelf Sci. 46, 457-464.

Primavera, J.H., 2000a. Development and conservation of Philippine mangroves: institutional issues. Ecol. Econ. 35, 91-106.

Primavera, J.H., 2000b. Integrated mangrove-aquaculture systems in Asia. Integr. Coast. Zone Manage. Autumn ed. 121-130.

Primavera, J.H., 2005. Mangroves, fishponds, and the quest for sustainability. Science 310, 57-59.

Primavera, J.H., Agbayani, R.F., 1997. Comparative strategies in community-based mangrove rehabilitation programmes in the Philippines. In: Hong, P.N., Ishwaran, N. San, H.T. Tri, N.H., Tuan, M.S. (Eds.), Proceedings of Ecotone V. Community Participation in Conservation, Sustainable Use and Rehabilitation of Mangroves in Southeast Asia, UNESCO, Japanese Man and the Biosphere National Committee and Mangrove Ecosystem Research Centre, Vietnam. pp. 229-243.

Primavera, J.H., de la Pena, L., 2000. The yellow mangrove: its ethnobotany, history of maritime collection, and needed rehabilitation in the central and southern Philippines. Philipp. Quart. Cult. Soc. 28, 464-475.

Primavera, J.H., Lebata, J.H., Altamirano, J., Gustilo, L., 2002. Collection of the clam Anodontia edentula in mangrove habitats in Panay and Guimaras, Central Philippines. Wetland Ecol. Manage. 10, 363-370.

Primavera, J.H., Sadaba, R.B., Lebata, M.J.H.L., Altamirano, J.P., 2004. Handbook of Mangroves in the Philippines-Panay. SEAFDEC Aquaculture Department (Philippines) and UNESCO Man and the Biosphere ASPACO Project, $106 \mathrm{pp}$.

Primavera, J.H., Altamirano, J.P., Lebata, M.J.H.L., de los Reyes Jr., A.A., Pitogo, C.L. 2007. Mangroves and shrimp pond culture effluents in Aklan, Panay Is., central Philippines. Bull. Mar. Sci. 80, 795-804.

Putz, F.E., Chan, H.T., 1986. Tree growth, dynamics, and productivity in a mature mangrove forest in Malaysia. For. Ecol. Manage. 17, 211-230.

Ramsey, E., Jensen, J.R., 1996. Remote sensing of mangrove wetlands: relating canopy spectra to site-specific data. Photogramm. Eng. Remote Sens. 62, 939-948.

Rasolofo, M.V., 1997. Use of mangroves by traditional fishermen in Madagascar. Mangr. Salt Marsh. 1, 243-253.

Rasolofoharinoro, M., Blasco, F., Bellan, M.F., Aizpuru, M., Gauquelin, T., Denis, J., 1998. A remote sensing based methodology for mangrove studies in Madagascar. Int. J. Remote Sens. 19, 1873-1886. 
Rist, S., Dahdouh-Guebas, F., 2006. Ethnosciences-a step towards the integration of scientific and traditional forms of knowledge in the management of natural resources for the future. Env. Dev. Sustain. 8, 467-493.

Rivera-Monroy, V.H., Twilley, R.R., Boustany, R.G., Day, J.W., Veraherrera, F., Ramirez, M.D., 1995. Direct denitrification in mangrove sediments in Terminos Lagoon, Mexico. Mar. Ecol. Progr. Ser. 126, 97-109.

Robertson, A.I., Duke, N.C., 1990a. Mangrove fish communities in tropical Queensland, Australia: spatial and temporal patterns in densities, biomass and community structure. Mar. Biol. 104, 369-379.

Robertson, A.I., Duke, N.C., 1990b. Recruitment, growth and residence time of fishes in a tropical Australian mangrove system. Estuar. coast. Shelf Sci. 31, 723-743.

Robertson, A.I., Phillips, M.J., 1995. Mangroves as filters of shrimp pond effluents: predictions and biogeochemical research needs. Hydrobiologia 295, 311321.

Rönnbäck, P., 1999. The ecological basis for economic value of seafood production supported by mangrove ecosystems. Ecol. Econ. 29, 235-252.

Rönnbäck, P., Troell, M., Primavera, J.H., Kautsky, N., 1999. Distribution pattern of shrimp and fish among Avicennia and Rhizophora microhabitats in the Pagbilao Mangroves, Philippines. Estuar. Coast. Shelf Sci. 48, 223-234.

Rönnbäck, P., Macia, A., Almqvist, G., Schultz, L, Troell, M., 2002. Do penaeid shrimps have a preference for mangrove habitats? Distribution pattern analysis on Inhaca Island, Mozambique. Est. Coast. Shelf Sci. 55, 427-436.

Rönnbäck, P., Troell, M., Zetterström, T., Babu, D.E., 2003. Mangrove dependence and socio-economic concerns in shrimp hatcheries of Andhra Pradesh, India. Environ. Conserv. 30, 344-352.

Rönnbäck, P., Crona, B., Ingwall, L., 2007a. The return of ecosystem goods and services in replanted mangrove forests-perspectives from local communities in Gazi Bay, Kenya. Environ. Conserv. 34, 313-324.

Rönnbäck, P., Troell, M., Kautsky, N., Pihl, L., Söderqvist, T., Wennhage, H., 2007b. Ecosystem goods and services from temperate coastal habitats - identification, valuation and implications of ecosystem shifts. Ambio 36, 534-544.

Roy, S.D., Krishnan, P., 2005. Mangrove stands of Andamans vis-à-vis tsunami. Curr. Sci. $89,1800-1804$

Ruitenbeek, H.J., 1994. Modeling economy-ecology linkages in mangroves: economic evidence for promoting conservation in Bintuni Bay, Indonesia. Ecol. Econ. 10, 233-247.

Saenger, P., 1996. Mangrove restoration in Australia: a case study of the Brisbane international airport. In: Field, C.D. (Ed.), Restoration of Mangrove Ecosystems. International Society for Mangrove Ecosystems, Okinawa, Japan, pp. 36-51.

Saenger, P., 2002. Mangrove Ecology, Silviculture and Conservation. Kluwer Academic Publishers/The Society for Mangrove Ecosystems/International Tropical Timber Organization, Dordrecht, The Netherlands/Okinawa, Japan.

Saenger, P., Siddiqi, N.A., 1993. Land from the sea: the mangrove afforestation program in Bangladesh. Ocean Coast. Manage. 20, 23-39.

Saenger, P., Hegerl, E.J., Davie, J.D.S., 1983. Global status of mangrove ecosystems Environmentalist 3 (Suppl. 3), 88.

Saito, H., Bellan, M.F., Al-Habshi, A., Aizpuru, M., Blasco, F. 2003. Mangrove research and coastal ecosystem studies with SPOT-4 HRVIR and TERRA ASTER in the Arabian Gulf. Int. J. Remote Sens. 24, 4073-4092.

Sánchez, L.M., Ruedas, D., Gómez, B.C., 2001. Gastric antiulcer effect of Rhizophora mangle L. J. Ethnopharm. 77, 1-3.

Sangdee, P., 1986. Health and sanitation among mangrove dwellers in Thailand. In: Kunstadter, P., Bird, E.C.F., Sabhasri, S. (Eds.), Man in the Mangroves. United Nations University, Tokyo, pp. 44-49.

Sathirathai, S., Barbier, E.B., 2001. Valuing mangrove conservation in southern Thailand. Contemp. Econ. Policy 19, 109-122.

Semesi, A.K., 1998. Mangrove management and utilization in Eastern Africa. Ambio 27, 620-626.

Serafy, J.E., Araújo, R.J. (eds.), 2007. Proceedings of the $1^{\text {st }}$ International Symposium on Mangroves as Fish Habitat. Bull. Mar. Sci. (special issue) 80, 451-935

Siddall, S.E., Atchue, J.A., III, Murray, P.L., Jr., 1985. Mariculture development in mangroves: a case study of the Philippines, Panama and Ecuador. In: Clark, J.R. (Ed.) Coastal Resources Management: Development Case Studies. Renewable Resources Information Series, Coastal Management Pub. No. 3. Prepared for the National Park Service, U.S. Dept. of the Interior, and the U.S. Agency for International Development. Research Planning Institute, Columbia, South Carolina, USA.

Simard, M., De Grandi, G., Saatchi, S., Mayaux, P., 2002. Mapping tropical coastal vegetation using JERS-1 and ERS-1 radar data with a decision tree classifier. Int. J. Remote Sens. 23, 1461-1474

Singh, H.R., Chong, V.C., Sasekumar, A., Lim, K.H., 1994. Value of mangroves as nursery and feeding grounds. In: Wilkinson, C.R., Suraphol, S., Chou, L.M. (Eds.), Proceedings of the Third ASEAN-Australia Symposium on Living Coastal Resources, vol. 1. Status Reviews, Chulalongkorn University, Bangkok, pp. 105-122.

Smith, A.H., Berkes, F., 1993. Community-based use of mangrove resources in St. Lucia. Int. J. Environ. Stud. 43, 123-131.

Spalding, M., Blasco, F., Field, C., 1997. World Mangrove Atlas. International Society for Mangrove Ecosystems, Okinawa, Japan.

Staples, D.J., Vance, D.J., Heales, D.S., 1985. Habitat requirement of juvenile penaeid prawns. In: Rothlisberg, P.C., Hill, B.J., Staples, D.S. (Eds.), Second National Prawn Seminar. NSP2, Cleveland, Australia, pp. 47-54

Stevenson, N.J., Lewis, R.R., Burbridge, P.R., 1999. Disused shrimp ponds and mangrove rehabilitation. In: Streever, W. (Ed.), An International Perspective on Wetland Rehabilitation. Kluwer Academic Publishers, Netherlands, pp. 277297.

Stone, R., 2006. A rescue effort for tsunami-ravaged Mangrove forests. Science 314 404-1404.

Stonich, S., Bailey, C., 2000. Resisting the blue revolution: contending coalitions surrounding industrial shrimp farming. Hum. Organiz. 59, 23-36.

Stonich, S., Vandergeest, P., 2001. Violence, environment, and industrial shrimp farming. In: Peluso, N.L., Watts, M. (Eds.), Violent Environments. Cornell University Press, Ithaca, New York, pp. 261-286.

Taylor, F.J., 1982. The utilization of mangrove areas in Thailand and Peninsular Malaysia. J. Southeast Asian Stud. 13, 1-8

Thorhaug, A., 1990. Restoration of mangroves and seagrasses-economic benefits for fisheries and mariculture. In: Berger, J.J. (Ed.), Environmental Restoration: Science and Strategies for Restoring the Earth. Island Press, Washington DC, pp. 265-281.

Tobisson, E., Andersson, J., Ngazi, Z., Rydberg, L., Cederlöf, U., 1998. Tides, monsoons and seabed: Local knowledge and practice in Chwaka Bay. Zanzibar. Ambio 27, 677-685.

Tomlinson, P.B., 1986. The Botany of Mangroves. Cambridge University Press, Cambridge.

Tong, P.H.S., Auda, Y., Populus, J., Aizpuru, M., Al-Habshi, A., Blasco, F., 2004. Assessment from space of mangrove evolution in the Mekong Delta, in relation to extensive shrimp farming. Int. J. Remote Sens. 25, 4795-4812.

Turner, R.E., 1977. Intertidal vegetation and commercial yields of penaeid shrimp. T. Am. Fish. Soc. 106, 411-416.

Twilley, R.R., Chen, R.H., Hargis, T., 1992. Carbon sinks in mangroves and their implications to carbon budget of tropical coastal ecosystems. Water Air Soil Pollut. 64, 264-288.

Untawale, A.G., 1987. Exploitation of mangroves in India. In: Field, C.D., Dartnall, A.J. (Eds.), Mangrove Ecosystems of Asia and the Pacific: Status, Exploitation and Management. Australian Development Assistance Bureau and Australian Committee for Mangrove Research, Townsville, pp. 220-227.

Valiela, I., Bowen, J.L., York, J.K., 2001. Mangrove forests: one of the world's threatened major tropical environments. BioSci. 51, 807-815.

Vance, D.J., Haywood, M.D.E., Heales, D.S., Kenyon, R.A., Loneragan, N.R., Pendrey, R.C., 1996. How far do prawns and fish move into mangroves? Distribution of juvenile banana prawns Penaeus merguiensis and fish in a tropical mangrove forest in northern Australia. Mar. Ecol. Prog. Ser. 131, 115-124.

Vandergeest, P., Flaherty, M., Miller, P., 1999. A political ecology of shrimp aquaculture in Thailand. Rural Sociol. 64, 573-596.

Vannucci, M., 2002. Indo-West pacific mangroves. In: Lacerda, L.D. (Ed.), Mangrove Ecosystems: Function and Management. Springer, New York, pp. 123-215.

Vayda, A.P., Walters, B.B., 1999. Against political ecology. Human Ecol. 27, 167179.

Vayda, A.P., Walters, B.B., Setyawati, I., 2004. Doing and knowing: questions about studies of local knowledge. In: Bicker, A., Sillitoe, P., Pottier, J. (Eds.), Investigating Local Knowledge: New Directions, New Approaches. Ashgate, London, pp. 35-58.

Vedeld, P., Angelsen, A., Sjaastad, E., Berg, G.K., 2004. Counting on the environment: Forest incomes and the rural poor. Environmental Economics Series Paper No. 98, World Bank, Washington, DC.

Verheugt, W.J.M., Purwoko, A., Danielsen, F., Skov, H., Kadarisman, R., 1991. Integrating mangrove and swamp forests conservation with coastal lowland development: the Banyuasin Sembilang swamps case study, South Sumatra Province, Indonesia. Landsc. Urban Plann. 20, 85-94.

Walsh, G.E., 1977. Exploitation of mangal. In: Chapman, V.J. (Ed.), Wet Coastal Ecosystems. Elsevier Science, New York, pp. 347-362.

Walters, B.B., 1997. Human ecological questions for tropical restoration: experiences from planting native upland forest and coastal mangrove trees in the Philippines. For. Ecol. Manage. 99, 275-290.

Walters, B.B., 2000. Local mangrove planting in the Philippines: are fisherfolk and fishpond owners effective restorationists? Restor. Ecol. 8, 237-246.

Walters, B.B., 2003. People and mangroves in the Philippines: fifty years of coastal environmental change. Environ. Conserv. 30, 293-303.

Walters, B.B., 2004. Local management of mangrove forests: effective conservation or efficient resource exploitation? Hum. Ecol. 32, 177-195.

Walters, B.B., 2005a. Patterns of local wood use and cutting of Philippine mangrove forests. Econ. Bot. 59, 66-76.

Walters, B.B., 2005b. Ecological effects of small-scale cutting of Philippine mangrove forests. For. Ecol. Manage. 206, 331-348.

Walters, B.B., 2006. Mangrove forests and environmental security. In: Innes, J.I., Edwards, I.K, Wilford, D.J. (Eds.), Forests in the balance: linking tradition and technology. Abstracts, XXII IUFRO World Congress, Brisbane, Australia, August 8-13, 2005. Int. For. Rev. 7(5), 290.

Walters, B.B., Burt, M., 1991. Integrated management of common property fuelwood resources from natural and plantation forests. CANARI Communication No. 35, Caribbean Natural Resources Institute, St. Lucia. Paper presented at the IDRC Workshop on Common Property Resources, Winnipeg, Canada, September 1991.

Walters, B.B., Sabogal, C., Snook, L., de Almeida, E., 2005. Constraints and opportunities for better silviculture practice in tropical forestry: an interdisciplinary approach. For. Ecol. Manage. 209, 3-18.

Walton, M.E., LeVay, L., Lebata, J.H., Binas, J., Primavera, J.H., 2006a. Seasonal abundance, distribution and recruitment of mud crabs (Scylla spp.) in replanted mangroves. Estuar. Coast. Shelf Sci. 66, 493-500. 
Walton, M.E., Samonte-Tan, G., Primavera, J.H., Edwards-Jones, G., Le Vay, L., 2006b. Are mangroves worth replanting? The direct economic benefits of a community-based reforestation project. Environ. Conserv. 33, 335-343.

Wang, L., Sousa, W.P., Gong, P., 2004a. Integration of object-based and pixel-based classification for mapping mangroves with IKONOS imagery. Int. J. Remote Sens $25,5655-5668$.

Wang, L., Sousa, W.P., Gong, P., Biging, G.S., 2004b. Comparison of IKONOS and QuickBird images for mapping mangrove species on the Caribbean coast of Panama. Remote Sens. Environ. 91, 432-440.

Watson, J.G., 1928. Mangrove Forests of the Malay Peninsula. Malayan Forester, Record No. 6. Federated Malay States.

Webb, E.L., Evangelista, M.A., Robinson, J.A., 2000. Digital land-use classification using space-shuttle-acquired orbital photographs: a quantitative comparison with Landsat TM imagery of a coastal environment, Chanthaburi, Thailand. Photogramm. Eng. Remote Sens. 66, 1439-1449.
Weinstock, J.A., 1994. Rhizophora mangrove agroforestry. Econ. Bot. 48, 210-213. Wells, S., Kapos, V., 2006. Coral reefs and mangroves: implications from the tsunami one year on. Oryx 40,123-124.

Wilkie, M.L., Fortuna, S., 2003. Status and trends in mangrove area extent worldwide. Working Paper FRA 63, Forest Resources Division, Forestry Department, UN-Food and Agriculture Organization, $292 \mathrm{pp}$.

Williams, N., 2005. Tsunami insight to mangrove value. Curr. Biol. 15, R73-R173.

Williams, M.J., Coles, R., Primavera, J.H., 2007. A lesson from cyclone Larry: an untold story of the success of good coastal planning. Estuar. Coast. Shelf Sci. 71, 364-367.

Wolanski, E., 1995. Transport of sediment in mangrove swamps. Hydrobiologia 295, 31-42.

Yanez-Arancibia, A., Lara-Dominguez, A.L., Day Jr., J.W. 1993. Interactions between mangrove and seagrass habitats mediated by estuarine nekton assemblages: coupling of primary and secondary productivity. Hydrobiologia 264, 1-12. 